\title{
Factor analysis of combined organic and inorganic aerosol mass spectra from high resolution aerosol mass spectrometer measurements
}

\author{
Y. L. Sun ${ }^{1}$, Q. Zhang ${ }^{2}$, J. J. Schwab ${ }^{3}$, T. Yang ${ }^{1}$, N. L. Ng$^{4}$, and K. L. Demerjian ${ }^{3}$ \\ ${ }^{1}$ State Key Laboratory of Atmospheric Boundary Layer Physics and Atmospheric Chemistry, \\ Institute of Atmospheric Physics, Chinese Academy of Sciences, Beijing, China \\ ${ }^{2}$ Department of Environmental Toxicology, University of California, Davis, California, USA \\ ${ }^{3}$ Atmospheric Sciences Research Center, State University of New York at Albany, Albany, New York, USA \\ ${ }^{4}$ School of Chemical and Biomolecular Engineering and School of Earth and Atmospheric Sciences, \\ Georgia Institute of Technology, Atlanta, Georgia, USA
}

Correspondence to: Y. L. Sun (sunyele@mail.iap.ac.cn)

Received: 1 May 2012 - Published in Atmos. Chem. Phys. Discuss.: 25 May 2012

Revised: 2 September 2012 - Accepted: 6 September 2012 - Published: 21 September 2012

\begin{abstract}
Positive matrix factorization (PMF) was applied to the merged high resolution mass spectra of organic and inorganic aerosols from aerosol mass spectrometer (AMS) measurements to investigate the sources and evolution processes of submicron aerosols in New York City in summer 2009. This new approach is able to study the distribution of organic and inorganic species in different types of aerosols, the acidity of organic aerosol (OA) factors, and the fragment ion patterns related to photochemical processing. In this study, PMF analysis of the unified AMS spectral matrix resolved 8 factors. The hydrocarbon-like OA (HOA) and cooking OA (COA) factors contain negligible amounts of inorganic species. The two factors that are primarily ammonium sulfate $\left(\mathrm{SO}_{4}-\mathrm{OA}\right)$ and ammonium nitrate $\left(\mathrm{NO}_{3}-\mathrm{OA}\right)$, respectively, are overall neutralized. Among all OA factors the organic fraction of $\mathrm{SO}_{4}$-OA shows the highest degree of oxidation $(\mathrm{O} / \mathrm{C}=0.69)$. Two semi-volatile oxygenated OA $(\mathrm{OOA})$ factors, i.e., a less oxidized (LO-OOA) and a more oxidized (MO-OOA), were also identified. MO-OOA represents local photochemical products with a diurnal profile exhibiting a pronounced noon peak, consistent with those of formaldehyde $(\mathrm{HCHO})$ and $\mathrm{O}_{\mathrm{x}}\left(=\mathrm{O}_{3}+\mathrm{NO}_{2}\right)$. The $\mathrm{NO}^{+} / \mathrm{NO}_{2}^{+}$ion ratio in MO-OOA is much higher than that in $\mathrm{NO}_{3}-\mathrm{OA}$ and in pure ammonium nitrate, indicating the formation of organic nitrates. The nitrogen-enriched OA (NOA) factor contains $\sim 25 \%$ of acidic inorganic salts, suggesting the formation of
\end{abstract}

secondary OA via acid-base reactions of amines. The size distributions of OA factors derived from the size-resolved mass spectra show distinct diurnal evolving behaviors but overall a progressing evolution from smaller to larger particle mode as the oxidation degree of OA increases. Our results demonstrate that PMF analysis of the unified aerosol mass spectral matrix which contains both inorganic and organic aerosol signals may enable the deconvolution of more OA factors and gain more insights into the sources, processes, and chemical characteristics of OA in the atmosphere.

\section{Introduction}

Atmospheric fine particles exert a serious impact on air quality and visibility reduction (Watson, 2002), and harmful effects on human health (Pope III et al., 2002, 2009). Organic aerosols (OA) - a major fraction of fine particles (Zhang et al., 2007a; Jimenez et al., 2009) have a highly uncertain impact on radiative forcing (Forster et al., 2007). Current models often underestimate OA loading substantially, mainly due to unknown sources, sinks, and formation mechanisms (e.g., aqueous-phase production of secondary OA) (Heald et al., 2005, 2011; Volkamer et al., 2006; Dzepina et al., 2009; Wood et al., 2010). Thus, a better understanding of the sources and evolution processes of OA is of importance for 
assessing aerosol's impacts and reducing the uncertainties in models.

OA from a wide variety of sources are either primary from direct emissions, e.g., combustion of fossil fuels and biomass burning, or secondary which is formed via gas-to-particle conversions such as oxidation of volatile organic compounds (VOCs) and/or aqueous-phase production. The atmospheric evolution such as aging, mixing, and cloud processing further leads to a change of the chemical, physical and optical properties of both primary OA (POA) and secondary OA (SOA). While the primary emissions of OA are fairly well understood, there are considerable uncertainties in quantification and characterization of SOA. The traditional ECtracer method (Turpin and Huntzicker, 1995) may involve large uncertainties in quantification of secondary organic carbon (SOC) due to either the differences in defining OC and EC from thermal-optical analysis (Khan et al., 2011) or variations in $\mathrm{OC} / \mathrm{EC}_{\text {primary }}$ ratio from different combustion emission sources. The molecular-marker based chemical mass balance $(\mathrm{CMB})$ receptor model is capable of quantifying the contributions of primary sources, but often a large fraction of secondary species remains uncharacterized (Schauer and Cass, 2000; Zheng et al., 2002). In addition, the techniques mentioned above often rely on measurements over hours to days, making it difficult to capture the fast evolution processes of OA in the atmosphere.

The Aerodyne Aerosol Mass Spectrometers (AMS) using thermal vaporization (typically $600{ }^{\circ} \mathrm{C}$ ) and electron impact ionization $(\sim 70 \mathrm{eV})$ allow us to obtain the ensemble mass spectra of OA in real time, typically in a few seconds to minutes (Jayne et al., 2000; Drewnick et al., 2005; DeCarlo et al., 2006). The custom principle component analysis (CPCA) was firstly used to deconvolve the OA into different factors that are associated with different sources and processes (Zhang et al., 2005a). The hydrocarbon-like OA (HOA), a surrogate of POA from traffic emissions, and oxygenated OA (OOA), a surrogate of SOA, were ubiquitously resolved at urban locations. HOA often shows tight correlations with the tracers for primary emissions, e.g., $\mathrm{NO}_{\mathrm{x}}, \mathrm{BC}$, and $\mathrm{CO}$, etc., while OOA is generally correlated with secondary inorganic species, e.g., sulfate and/or nitrate (Zhang et al., 2005b). The multiple component analysis (MCA) was further developed to characterize the potential sub-OOA factors, e.g., highly oxidized OOA (OOA-I) and less oxidized OOA (OOA-II) (Zhang et al., 2007a). MCA analysis of 37 AMS datasets in the Northern Hemisphere shows an overall dominance of OOA at various atmospheric environments from urban, urban downwind, to rural and remote sites (Zhang et al., 2007a). The positive matrix factorization (PMF) (Paatero and Tapper, 1994), a bilinear model that constrains the factors to be non-negative is currently mostly used for OA mass spectra analysis (Lanz et al., 2007; Ulbrich et al., 2009; Zhang et al., 2011). Various POA components like HOA, cooking OA (COA), and biomass burning OA (BBOA), and SOA components like semi-volatile OOA (SV-OOA) and low-volatility
OOA (LV-OOA) are broadly identified depending on sites, seasons, and source emissions. The OA factors together with the measurements of hygroscopicity, volatility, and oxidation states significantly improve our understanding of the sources and evolution processes of OA in the atmosphere (Jimenez et al., 2009).

The recent PMF analysis of high resolution mass spectra (HRMS) further improves the differentiation of OA factors and also allows us to determine the oxidation state of each factor (Aiken et al., 2009; DeCarlo et al., 2010; Sun et al., 2011c). Given that the atmospheric evolution of OA might involve a progressive oxidation from fresh to highly aged OA associated with a change of functionalities, volatilities, and oxidative properties (Heald et al., 2010; $\mathrm{Ng}$ et al., 2010; Sun et al., 2011b), more sub-OOA factors are expected, but difficult to be resolved due to a lack of collocated variables. Slowik et al. (2010b) firstly combined the OA spectra from AMS measurements with the VOCs measured by a proton transfer reaction-mass spectrometer (PTR-MS). PMF analysis of the unified dataset shows the capability of resolving more OOA factors and improving the interpretations of their sources and photochemical processes. Docherty et al. (2011) performed the PMF analysis to the combined ambient and thermally denuded OA spectra (TD-PMF-AMS) during the 2005 Study of Organic Aerosols at Riverside (SOAR-1). The TD-PMF-AMS with improved differentiation of OA factors identified two more secondary OOA factors in addition to the previous SV-OOA and LV-OOA. Despite this, the two approaches above are often limited by the collocated measurements of VOCs by PTR-MS or thermally denuded OA spectra that are not available in field studies. Chang et al. (2011) first tried to perform PMF on the entire unit mass resolution spectra measured by a compact Time-of-Flight AMS over the central Arctic Ocean. This approach successfully distinguished marine biogenic and continental sources. However, most previous PMF analysis is only performed on AMS OA spectra, while the inorganic species, e.g., sulfate and nitrate are used as external tracers for comparison purpose. Since the organic and inorganic species from different sources and formation mechanisms are often externally or internally mixed as a function of aerosol evolution in the atmosphere, PMF analysis of OA spectra only may bury the intrinsic relationship between organic and inorganic species.

In this study, we re-analyze the three-week HRMS of organic and inorganic aerosols (IOA) measured by an Aerodyne High Resolution Time-of-Flight AMS (HR-ToF-AMS, DeCarlo et al., 2006) at Queens College in New York City (NYC) in summer, 2009 (Sun et al., 2011c). For the first time, we integrate the organic and inorganic HR spectral matrices into one unified dataset for PMF analysis. The sources, acidity, and photochemical processing of OA and IOA are investigated. In addition, the size distributions of OA factors are derived from 3-dimensional size-resolved mass spectra, and their implications in studying the sources and processes of $\mathrm{OA}$ are discussed. 


\section{Method}

\subsection{AMS measurements and data analyses}

The HR-ToF-AMS was deployed on the campus of Queens College $\left(40.74^{\circ} \mathrm{N}, 73.82^{\circ} \mathrm{W}\right)$ in NYC from 13 July through 3 August 2009 for in-situ measurements of the mass concentrations, chemical composition and size distributions of non-refractory submicron aerosol (NR-PM 1 ) species. The descriptions of the sampling site and operations of the HR-ToF-AMS and collocated instruments have been detailed in Sun et al. (2011c) and Lin et al. (2012). The HR-ToF-AMS data were re-analyzed with the latest versions of standard AMS software (PIKA v1.10H and SQUIRREL $\quad \mathrm{v} 1.51 \mathrm{H}$; http://cires.colorado.edu/jimenez-group/ ToFAMSResources/ToFSoftware/index.html). Compared to Sun et al. (2011c), a major update of the new software is the calculation of ion counting errors. However, such update appears to show minor effects on the PMF results, which is supported by the very similar spectral patterns of OA factors in these two studies $\left(r^{2}=0.99-1.0\right.$, slope $\left.=0.99-1.02\right)$. The mass concentrations and size distributions of NR-PM species, and the elemental composition of OA were obtained. In addition, the high resolution (HR) mass spectral matrices and 3-dimensional size-resolved mass spectra were extracted for the subsequent PMF analysis and size deconvolution. All data in this study is reported at Eastern Standard Time $(\mathrm{EST}=\mathrm{UTC}-5 \mathrm{~h})$.

\subsection{Preparation of mass spectral and error matrices}

The procedures for preparation of HR mass spectral and error matrices for PMF analysis have been detailed in DeCarlo et al. (2010). The HR data matrix was obtained by the difference of "Open" and "Closed" ion sticks, i.e., "OMinusC" in HR analysis panel. The corresponding HR error matrix was determined as the sum of quadrature of Poisson counting statistics and electronic noise for each ion (Allan et al., 2003). Note that the ion counting errors in the latest version of PIKA also included baseline errors. Also, a minimum error was introduced for each ion (Ulbrich et al., 2009). The "bad" ions with signal-to-noise $(\mathrm{S} / \mathrm{N})$ ratio $<0.2$ were removed from the HR data and error matrices, and the "weak" ions with $\mathrm{S} / \mathrm{N}$ between 0.2 and 2 were downweighed by increasing their error values a factor of 2 as described in Ulbrich et al. (2009). In addition, the particulate ion $\mathrm{CO}_{2}^{+}$and its associated $\mathrm{CO}^{+}, \mathrm{H}_{2} \mathrm{O}^{+}, \mathrm{HO}^{+}$, and $\mathrm{O}^{+}$were also downweighed according to Ulbrich et al. (2009). Both the HR data and error matrices were converted from ion signals to mass concentrations before PMF analysis. Following the same procedures, the mass spectral and error matrices of inorganic fragment ions including sulfate, nitrate, ammonium, and chloride were prepared and integrated with those of OA into one unified dataset. However, only major fragment ions for each inorganic species are included. They are $\mathrm{SO}^{+}(m / z 48)$,
$\mathrm{SO}_{2}^{+}(m / z 64), \mathrm{SO}_{3}^{+}(m / z 80), \mathrm{HSO}_{3}^{+}(m / z 81)$, and $\mathrm{H}_{2} \mathrm{SO}_{4}^{+}$ $\left(m / z\right.$ 98) for sulfate, $\mathrm{NO}^{+}\left(m / z\right.$ 30) and $\mathrm{NO}_{2}^{+}(m / z$ 46) for nitrate, $\mathrm{NH}^{+}(m / z 15), \mathrm{NH}_{2}^{+}(m / z 16), \mathrm{NH}_{3}^{+}(m / z 17)$ for ammonium, and $\mathrm{Cl}^{+}(m / z 35)$ and $\mathrm{HCl}^{+}(m / z 36)$ for chloride. Ions that are constrained, i.e., scaled to ion intensities (e.g., according to the known isotope ratios for isotopic ions), are not included. The sum of selected fragment ions represents a major fraction of nitrate $(96.2 \%)$, ammonium $(99.6 \%)$ and chloride $(75.8 \%)$, and $\sim$ half of sulfate $(50.6 \%)$, respectively. Further, these fragment ions show very tight correlations with the total mass concentration of each species $\left(r^{2} \approx 1\right.$, Fig. S1 in Supplement), indicating that the selected ions are well representative of each inorganic species. Similarly, the inorganic fragment ions before PMF analysis were also converted to mass concentrations in both data and error matrices. After PMF analysis, the total mass concentration of each inorganic species is derived from the sum of fragment ions divided by their fractional contributions in the corresponding species (Fig. S1).

\subsection{Positive matrix factorization (PMF)}

As a standard multivariate factor analysis approach, PMF (Paatero and Tapper, 1994) uses the positively constrained bilinear model to deconvolve the HR mass spectral matrix $\left(x_{i j}\right.$; dimensions: $m \times n)$ into distinct factors $(p)$ without a priori assumptions for either time series or mass spectral profiles.

$x_{i j}=\sum_{p} g_{i p} f_{p j}+e_{i j}$

where $i$ and $j$ refer to row and column indices in the matrix, respectively, and $p$ is the number of factors in the solution. $x_{i j}$ is the measured concentrations of ion fragment $j$ at timestep $i . g_{i p}$ is the concentration of a given factor $p$ at time-step $i$, and $f_{p j}$ is the fraction of an ion fragment $j$ in the mass spectral profile of factor $p$, and $e_{i j}$ is the residual not fit by the model. PMF solves Eq. (1) by minimizing the sum of the error weighed squared residuals (" $Q$ ").

$Q=\sum_{i=1}^{m} \sum_{j=1}^{n}\left(e_{i j} / \sigma_{i j}\right)^{2}$

where $\sigma_{i j}$ is the estimated error of ion fragment $j$ at time-step $i$ in the $m \times n$ matrix. The solutions are constrained to be positive which is physically meaningful in real atmospheric environment. The PMF analysis using PMF2 algorithm (v 4.2) in robust mode was performed on the combined HR matrices of OA and IOA. The PMF2 solutions were then evaluated with an Igor Pro-based PMF Evaluation Tool (PET, v2.04) (Ulbrich et al., 2009) following the procedures detailed in Zhang et al. (2011) (Fig. S2). The PMF analysis was also performed on the HR matrices of OA, and the results of 5factor solution were already presented in Sun et al. (2011c).

After a detailed evaluation of mass spectral profiles, time series, diurnal variations, and correlations with external tracers, the 8 -factor solution with FPEAK $=0\left(Q / Q_{\exp }=1.5\right)$ 
was chosen. The mass spectral profiles, time series, and diurnal variations of 7-factor and 9-factor solutions are shown in Figs. S3 and S4, respectively. While the results of 7-factor solution are very similar to those reported in Sun et al. (2011c), the 9-factor solution appears to show a split of $\mathrm{SO}_{4}$-OA that is difficult to interpret. Thus, we selected the 8-factor solution in this study. The eight factors identified include two primary factors, i.e., a hydrocarbon-like $\mathrm{OA}(\mathrm{HOA}, \mathrm{O} / \mathrm{C}=0.04)$ and a cooking $\mathrm{OA}(\mathrm{COA}, \mathrm{O} / \mathrm{C}=0.13)$, two semi-volatile oxygenated OA (OOA) factors, i.e., a more oxidized (MO-OOA, $\mathrm{O} / \mathrm{C}=0.48$ ) and a less oxidized (LO-OOA, $\mathrm{O} / \mathrm{C}=0.27$ ), a low volatility OOA (LV-OOA, $\mathrm{O} / \mathrm{C}=0.59$ ), a nitrogenenriched $\mathrm{OA}(\mathrm{NOA}, \mathrm{O} / \mathrm{C}=0.28$ ), and two factors that are primarily ammonium sulfate $\left(\mathrm{SO}_{4}-\mathrm{OA}, \mathrm{O} / \mathrm{C}=0.69\right)$ and ammonium nitrate $\left(\mathrm{NO}_{3}-\mathrm{OA}, \mathrm{O} / \mathrm{C}=0.14\right)$. The rotational ambiguity of the 8 -factor solution was explored by varying the initial FPEAK values. The mass spectra and time series of the factors for selected FPEAK values are shown in Fig. S5. While the factor profiles and time series are reasonably consistent for most PMF factors, the NOA and MO-OOA appear to show relatively higher uncertainties. Table $\mathrm{S} 1$ gives a summary of the fractional contributions of the PMF factors associated with rotational ambiguity. The PMF solution was further justified through the comparisons of the time series of the factors with those of tracer species. As shown in Fig. S6, the FPEAK $=0$ solution presents the best correlations between PMF factors and external tracer species. Since we do not have specific reasons for choosing other FPEAK values, the PMF solution with FPEAK $=0$ is thus chosen.

We also compared the 8-factor solution results in this study with the 5-factor solution from the PMF analysis of OA spectra matrix reported in Sun et al. (2011c). As shown in Figs. 1 and S7, HOA and COA show very similar spectral patterns and time series between these two studies. This suggests that PMF analysis of the combined HR matrices has minor effects on POA factors, consistent with the different sources of POA from secondary species. However, the new approach appear to split the previous SV-OOA and LV-OOA in Sun et al. (2011c) into LO-OOA and MO-OOA, and LV-OOA and $\mathrm{SO}_{4}-\mathrm{OA}$, respectively, in this study. Indeed, the combined mass spectra and time series of LO-OOA and MO-OOA, and $\mathrm{LV}-\mathrm{OOA}$ and $\mathrm{SO}_{4}-\mathrm{OA}$ are very similar to those of SV-OOA and LV-OOA, respectively, in Sun et al. (2011c) (Figs. 1c, d and S7c, d). Due to the absence of collocated measurement of HCHO in Sun et al. (2011c), the PMF resolution was limited to 5 factors. Here, the OA mass spectra were re-analyzed with $\mathrm{PMF}$, and the resolution was extended to 6-factor, i.e., HOA, COA, NOA, LO-OOA, MO-OOA, and LV-OOA. The results of this 6-factor solution are then compared with 8factor solution from PMF analysis of the combined spectra in Fig. S8. Again, the POA factors of HOA and COA from the two different approaches show much similarity in both spectral profiles and time series. While the spectral patterns are overall similar, the OOA factors show some differences
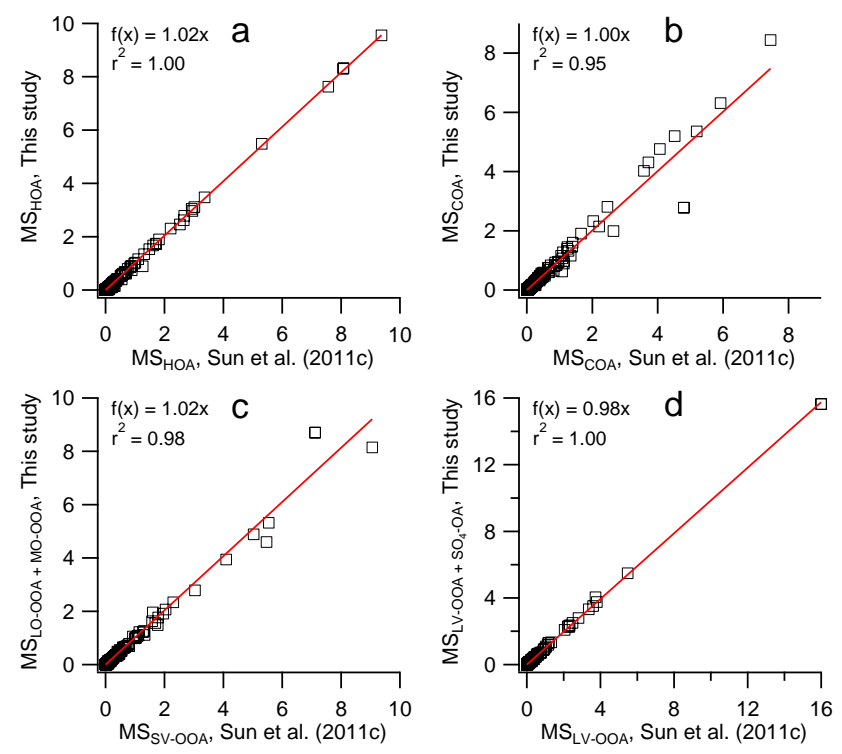

Fig. 1. Mass spectra (MS) comparison of (a) HOA, (b) COA, (c) $\mathrm{LO}-\mathrm{OOA}+\mathrm{MO}-\mathrm{OOA}$ vs. SV-OOA, and (d) $\mathrm{LV}-\mathrm{OOA}+\mathrm{SO}_{4}-\mathrm{OA}$ vs. LV-OOA from 8-factor solution of PMF analysis of the combined organic and inorganic aerosols in this study and 5-factor solution of PMF analysis of OA in Sun et al. (2011c).

in time series, mainly due to the apportionment of part OOA into $\mathrm{SO}_{4}$-OA factor.

\subsection{Determination of the size distributions of $\mathrm{OA}$ factors}

The size distributions of OA factors are of importance for investigation of their properties, hygroscopicity, and evolution processes. Recently, a 3-dimensional (3-D; dimensions: date/time, size, and $m / z$ ) factorization models was developed to derive the size distribution of OA factors (Ulbrich et al., 2012). Given that we have difficulties to perform such analysis in this study, we apply the multiple linear regression (MLR) technique (Eq. 3) to the 3-D size-resolved mass spectra for determination of the size distributions of OA assuming that (1) the mass spectrum is a linear combination of six OA factors, i.e., HOA, COA, NOA, LO-OOA, MOOOA, and LV-OOA, and (2) the mass spectra of OA factors are constant across the whole size ranges.

$\mathrm{MS}_{i, j}=\sum_{p=1}^{6} c_{i, j, p} \times \mathrm{ms}_{\mathrm{OA}, p}$

where $\mathrm{MS}_{i j}$ is the mass spectrum of OA at size bin $j$ and time-step $i \cdot \mathrm{ms}_{\mathrm{OA}, p}$ is the normalized mass spectrum of OA factor $p$, and $c_{i, j, p}$ is the linear regression coefficients in $\mathrm{d} M \operatorname{d} \log D_{\text {va }}\left(\mu \mathrm{g} \mathrm{m}^{-3}\right)$ which is constrained to be nonnegative. Note that the six OA spectra used for regression analysis are the 6-factor solution results from PMF analysis of the OA-only spectra. We also tried MLR analysis with the eight OA factors determined from PMF analysis of the 

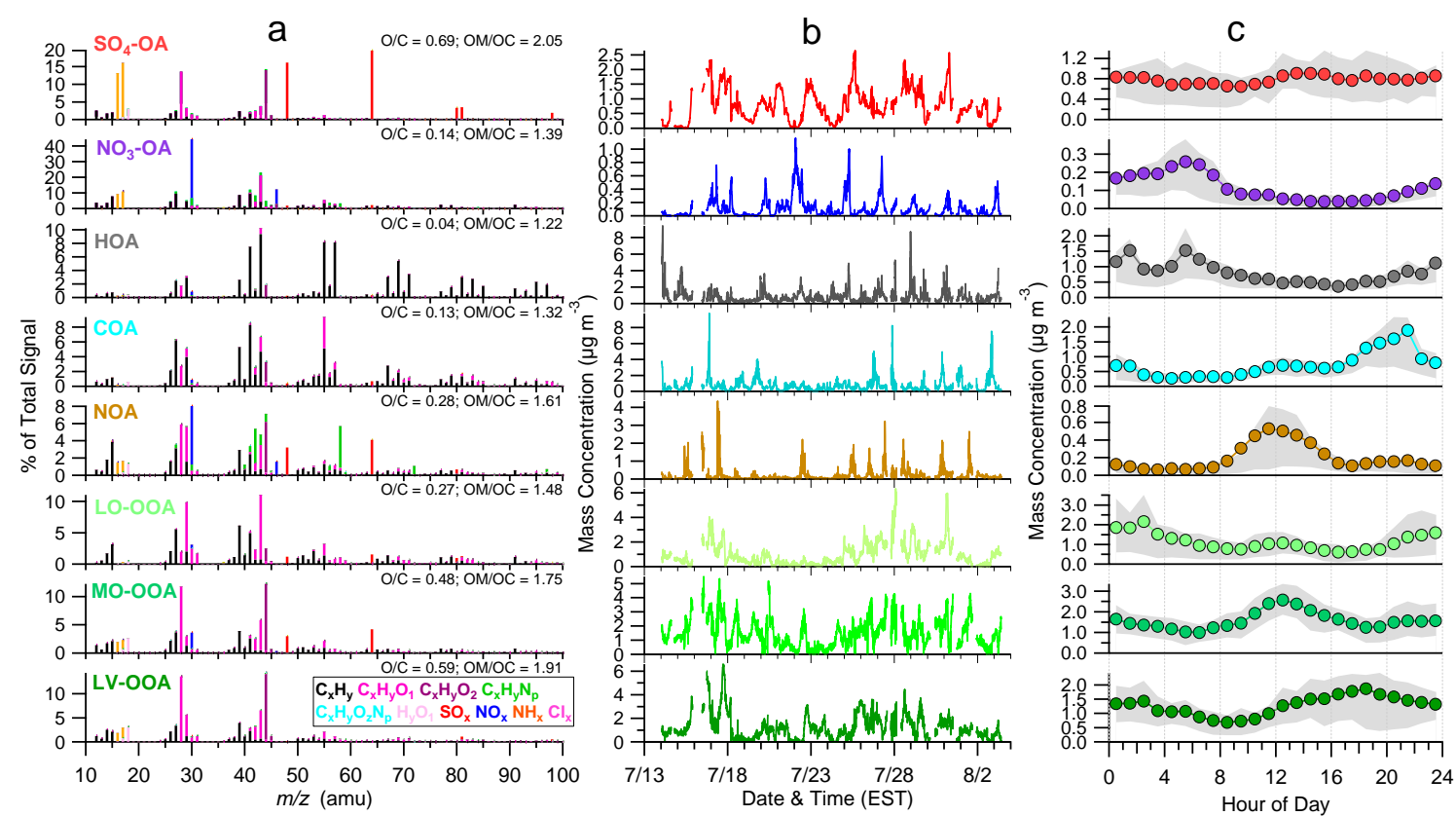

Fig. 2. (a) High resolution mass spectra of PMF factors. The mass spectra of $\mathrm{OA}$ in $\mathrm{SO}_{4}-\mathrm{OA}$ and $\mathrm{NO}_{3}-\mathrm{OA}$ are enhanced by a factor of 3 and 10 , respectively, for clarity. (b) Diurnal profiles of OA in each factor. The solid circles refer to mean values, and the gray shaded areas are 25 th and 75 th percentiles.

combined organic and inorganic aerosol spectra. The results are presented in Fig. S9 and compared with those from the six OA factor analysis. As shown in Fig. S9, the average size distributions of HOA, COA, NOA, LO-OOA, MO-OOA, and LV-OOA from the two analyses agree reasonably well. Considering that the $\mathrm{SO}_{4}-\mathrm{OA}$ and $\mathrm{NO}_{3}$-OA factors are primarily ammonium sulfate and ammonium nitrate, respectively, similar size distributions between sulfate and $\mathrm{SO}_{4}-\mathrm{OA}$, and between nitrate and $\mathrm{NO}_{3}-\mathrm{OA}$ are expected. However, we note that the size distribution of $\mathrm{SO}_{4}-\mathrm{OA}$ is quite different from sulfate while that of $\mathrm{NO}_{3}-\mathrm{OA}$ is somewhat similar to nitrate. One explanation is that the similar spectral patterns between $\mathrm{SO}_{4}-\mathrm{OA}$ and LV-OOA, and the dominated two large peaks of $m / z 28$ and 44 peaks in the spectrum of $\mathrm{SO}_{4}$-OA might have increased the uncertainties of linear regression coefficients. Thus, all the size distributions of OA factors in this study are the results from MLR analysis of six OA factors from PMF analysis of OA spectra. In addition, only size-resolved mass spectra between 50-1200 nm were analyzed due to low $\mathrm{S} / \mathrm{N}$ ratio below $50 \mathrm{~nm}$ and above $1200 \mathrm{~nm}$. The size distribution of each OA factor is finally normalized by integrating the signals between $50-1200 \mathrm{~nm}$ to the corresponding mass concentration of the factor. The MLR approach was further evaluated by comparing with the results from tracer$\mathrm{m} / \mathrm{z}$ based method. Because it's difficult to find specific $\mathrm{m} / \mathrm{z}$ for each factor, we only compared the MLR results of HOA and OOA from 2-factor solution of PMF analysis of only OA with those from tracer- $m / z$ based method. Note HOA from the 2-factor solution is approximately the sum of HOA and COA from 6-factor solution, and OOA is approximately the sum of LV-OOA, MO-OOA, LO-OOA, and NOA. The tracer $m / z 44$ and $m / z 57$ by subtracting its OOA contribution (mainly $\mathrm{C}_{3} \mathrm{H}_{5} \mathrm{O}^{+}$) were used to derive the size distributions of OOA and HOA, respectively, as described in previous studies (Zhang et al., 2005b; Sun et al., 2011c; Ge et al., 2012). As shown in Fig. S10, the size distributions of HOA and OOA from the two approaches show reasonably agreements across the whole day. While the size distribution of OOA is more similar, HOA has some differences with generally higher concentrations below $\sim 100 \mathrm{~nm}$ for the tracer$m / z$ method.

\section{Results and discussion}

The mass spectral profiles of the eight factors and their diurnal variation patterns are shown in Fig. 2. The chemical composition of each PMF factor and the distribution of PMF factors in each NR-species are shown in Fig. 3 and Table 1. In the following sections, we will discuss the mass spectra, diurnal variations, size distributions, and potential sources and processes of these factors.

\section{1 $\mathrm{SO}_{4}-\mathrm{OA}$ and $\mathrm{NO}_{3}-\mathrm{OA}$}

The $\mathrm{SO}_{4}$-OA factor is primarily composed of ammonium sulfate, which accounts for $82 \%$ of the total mass of this factor (Fig. 3b). The $\mathrm{SO}_{4}$-OA shows tight correlation $\left(r^{2}=0.97\right)$ with sulfate and the oxygenated ion $\mathrm{CO}_{2}^{+}\left(\mathrm{m} / z 44, r^{2}=\right.$ 


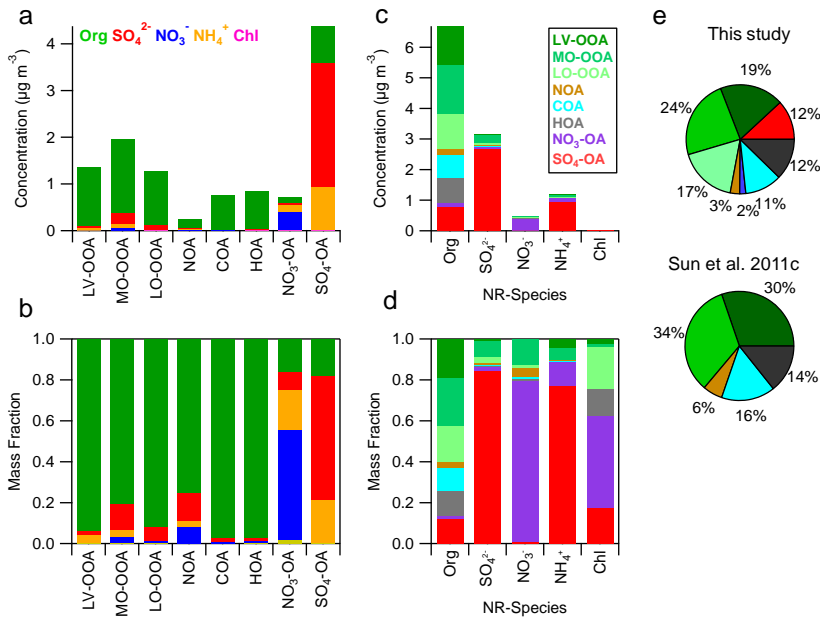

Fig. 3. (a, b) Chemical composition of PMF factors, i.e., mass concentrations and mass fractions of NR-species (organics, sulfate, nitrate, ammonium, and chloride) in each factor; $(\mathbf{c}, \mathbf{d})$ Distribution of PMF factors in each NR-species; (e) Average composition of OA in this study and 5-factor OA (LV-OOA, SV-OOA, HOA, COA, and NOA) composition in Sun et al. (2011c).

0.53; Fig. 4). Note that $18 \%$ of the mass of this factor is organic with a high degree of oxidation $(\mathrm{O} / \mathrm{C}=0.69)$. The organics in this factor is the most oxidized among the eight factors identified in this study (Fig. 2a). The diurnal profile of $\mathrm{SO}_{4}-\mathrm{OA}$ is relatively flat (Figs. $2 \mathrm{~b}$ and $5 \mathrm{a}$ ), very similar to that of sulfate (Sun et al., 2011c). These results suggest that $\mathrm{SO}_{4}-\mathrm{OA}$ is a highly aged secondary factor which is likely from regional transport. Indeed, sulfate in the $\mathrm{SO}_{4}-\mathrm{OA}$ factor contributes $84 \%$ of the total sulfate mass, consistent with previous findings that $\sim 90 \%$ of sulfate in NYC is from regional transport (Lall and Thurston, 2006; Qin et al., 2006). In comparison, sulfate in the rest of the OA factors shows a pronounced noontime peak (Fig. 5a), in agreement with the peaking of gas-phase production rate of $\mathrm{H}_{2} \mathrm{SO}_{4}$. It should be noted that photochemical production of organosulfates might also have played a role in the noon peak. Nevertheless, the results suggest different sources of sulfate in $\mathrm{SO}_{4}-\mathrm{OA}$ compared to sulfate associated with the other factors. In addition, the $\mathrm{SO}_{4}-\mathrm{OA}$ factor contains negligible amount of nitrate, likely due to (1) different formation mechanisms, although they are both secondary products, and (2) ammonium nitrate is more volatile, which is less favorable for long-range transport.

The $\mathrm{NO}_{3}-\mathrm{OA}$ factor is dominantly composed of ammonium nitrate $(74 \%)$ with the $\mathrm{NO}^{+} / \mathrm{NO}_{2}^{+}$ratio (3.6) close to the value (3.5) determined in pure ammonium nitrate. The nitrate in $\mathrm{NO}_{3}-\mathrm{OA}$ accounts for $\sim 80 \%$ of total nitrate. The diurnal cycle of $\mathrm{NO}_{3}-\mathrm{OA}$ shows elevated concentration in early morning when the air temperature is low and the relative humidity is high (Fig. S10). The $\mathrm{NO}_{3}-\mathrm{OA}$ concentration drops rapidly during daytime and shows a minimum
Table 1. Summary of mass concentrations $\left(\mu \mathrm{g} \mathrm{m}^{-3}\right)$ of NR species in PMF factors.

\begin{tabular}{lccccc}
\hline PMF Factors & Org & $\mathrm{SO}_{4}$ & $\mathrm{NO}_{3}$ & $\mathrm{NH}_{4}$ & $\mathrm{Chl}$ \\
\hline $\mathrm{SO}_{4}$-OA & 0.785 & 2.665 & 0.003 & 0.920 & 0.004 \\
$\mathrm{NO}_{3}$-OA & 0.118 & 0.060 & 0.387 & 0.140 & 0.011 \\
$\mathrm{HOA}$ & 0.818 & 0.011 & 0.005 & 0.004 & 0.003 \\
$\mathrm{COA}$ & 0.741 & 0.015 & 0.004 & 0.002 & 0.000 \\
$\mathrm{NOA}$ & 0.194 & 0.036 & 0.021 & 0.007 & 0.000 \\
LO-OOA & 1.175 & 0.086 & 0.008 & 0.003 & 0.005 \\
MO-OOA & 1.576 & 0.254 & 0.061 & 0.067 & 0.000 \\
LV-OOA & 1.278 & 0.030 & 0.001 & 0.054 & 0.001 \\
\hline
\end{tabular}

in the late afternoon. Such diurnal variation is consistent with the diurnal profile of the equilibrium constant $\left(K_{\mathrm{p}}\right)$ of $\mathrm{NH}_{3}(\mathrm{~g})+\mathrm{HNO}_{3}(\mathrm{~g}) \rightarrow \mathrm{NH}_{4} \mathrm{NO}_{3}(\mathrm{~s})$, indicating that the partitioning between particle-phase nitrate and gas-phase $\mathrm{HNO}_{3}$ might have played a major role (Sun et al., 2011c). The nitrate in the rest of the OA factors presents a pronounced noon peak, consistent with the diurnal profile of gas-phase production of $\mathrm{HNO}_{3}$ (Fig. 5b), which illustrates a dominant source of nitrate from photochemical production for these factors. The results above suggest that PMF analysis of the combined OA and IOA is able to reveal the two different formation mechanisms of nitrate. Note that this factor contains the majority of the total chloride (45\%) that mainly exists in the form of $\mathrm{NH}_{4} \mathrm{Cl}$ at the typical AMS vaporizer temperatures $\left(600^{\circ} \mathrm{C}\right)$. The similar volatile characteristics of $\mathrm{NH}_{4} \mathrm{Cl}$ as $\mathrm{NH}_{4} \mathrm{NO}_{3}$ further demonstrate the role of gas-to-particle partitioning in controlling this factor. The $\mathrm{NO}_{3}-\mathrm{OA}$ factor includes $17 \%$ fresh $\mathrm{OA}(\mathrm{O} / \mathrm{C}=0.14)$, likely due to the condensation of fresh organic vapors on the nitrate particles, especially at nighttime. Note that the majority of the nitrate and sulfate signals are apportioned into $\mathrm{NO}_{3}-\mathrm{OA}$ and $\mathrm{SO}_{4}$ $\mathrm{OA}$, respectively, due to their different formation mechanisms and evolution processes. Of importance, the OA mixed within these two factors are quite different with different spectral patterns and oxidation degrees, supporting their different sources and processes. In comparison, previous PMF analysis of filter-based fine particle composition in New York offered much less information of OA although separate factors of secondary sulfate and secondary nitrate were also identified (Li et al., 2004; Qin et al., 2006).

\subsection{HOA and COA}

Similar to previously identified POA factors in NYC (Sun et al., 2011c), the HOA and COA show mass spectral profiles resembling those from gas/diesel exhaust (Canagaratna et al., 2004) and cooking emissions (Mohr et al., 2009; Allan et al., 2010), respectively. The HOA spectrum is characterized by the hydrocarbon ion series of $\mathrm{C}_{n} \mathrm{H}_{2 n+1}^{+}$and $\mathrm{C}_{n} \mathrm{H}_{2 n-1}^{+}$, and very low $\mathrm{O} / \mathrm{C}$ ratio $(=0.04)$, while the $\mathrm{COA}$ shows higher $\mathrm{O} / \mathrm{C}$ ratio $(=0.13)$, and higher $m / z \quad 55 / 57$ ratio $(=2.9)-\mathrm{a}$ 


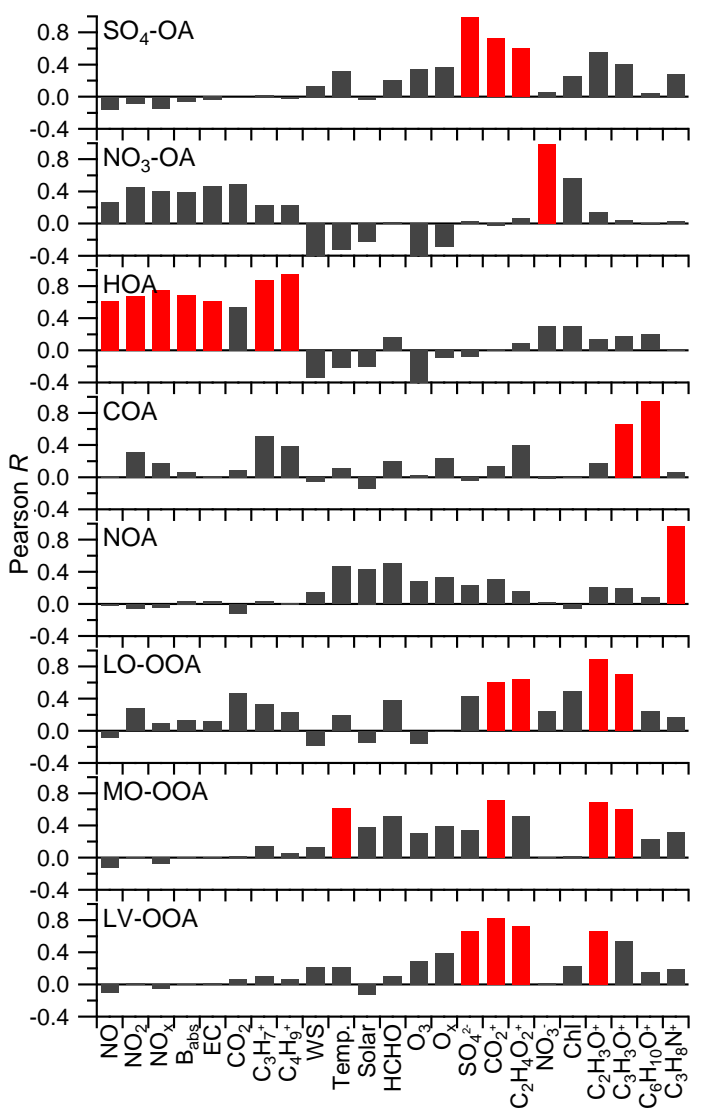

Fig. 4. Correlation coefficients of PMF factors versus external tracers. The correlation coefficients with the values larger than 0.6 are marked as red.

signature indicating the presence of COA (Mohr et al., 2012). The diurnal variations of HOA and COA are also consistent with the emissions from traffic exhaust and cooking activities which are characterized by the distinct peaks corresponding to the specific times, e.g., traffic hours in the morning and meal times at noon and evening. While the HOA shows tight correlations with most of the tracers for primary emissions, e.g., $\mathrm{NO}_{\mathrm{x}}, B_{\mathrm{abs}}$, EC, etc., the COA shows the best correlation with some specific ions, e.g., $\mathrm{C}_{3} \mathrm{H}_{3} \mathrm{O}^{+}$and $\mathrm{C}_{6} \mathrm{H}_{10} \mathrm{O}^{+}$ (Fig. 4). HOA and COA together account for $23 \%$ of total OA, which is slightly lower than $30 \%$ previously reported in NYC (Sun et al., 2011c). Note that the two primary factors are almost completely organics $(>97 \%)$ with little inorganic ammonium sulfate and ammonium nitrate. This is evidence for different sources of primary organic particles and secondary inorganic species.

Figure 6 shows the diurnal evolution of the size distributions of six OA factors and Fig. 7 presents the average size distributions for the entire study. The diurnal cycle of HOA size distribution shows a bimodal distribution in both midnight and morning rush hours when the small mode particles peaking at $\sim 110 \mathrm{~nm}$ are largely enhanced. Such feature is further illustrated by the average size distributions between

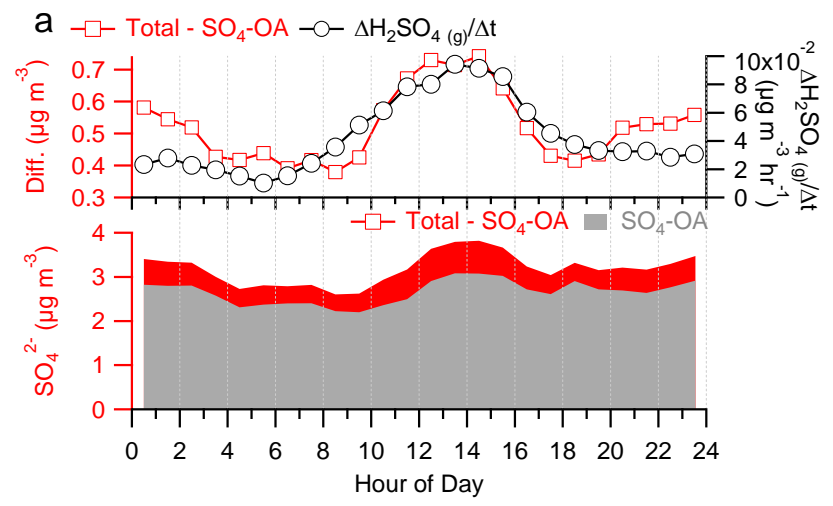

b $-\square-$ Total $-\mathrm{NO}_{3}-\mathrm{OA}-\mathrm{O}-\triangle \mathrm{HNO}_{3}(\mathrm{~g}) / \Delta \mathrm{t}$

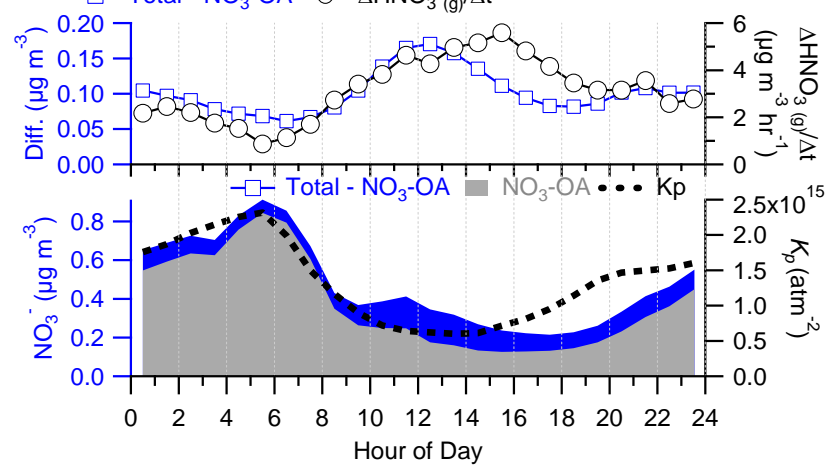

Fig. 5. Diurnal cycles of (a) sulfate in $\mathrm{SO}_{4}-\mathrm{OA}$ and the rest of the $\mathrm{OA}$ factors, and the estimated gas-phase production rate of $\mathrm{H}_{2} \mathrm{SO}_{4}$ (Sun et al., 2011c), (b) nitrate in $\mathrm{NO}_{3}$-OA and the rest of $\mathrm{OA}$ factors, the estimated gas-phase production rate of $\mathrm{HNO}_{3}$, and equilibrium constant of $K_{\mathrm{p}}$ (Sun et al., 2011c).

06:00-08:00 EST on 25 July when HOA dominated OA composition (35\%, Fig. $7 \mathrm{c})$. The small particle mode gradually dissipates during daytime while the contribution of the large mode increases correspondingly. The average HOA size also shows a considerable fraction at accumulation mode, likely from the emissions of large HOA particles and/or the growth of small HOA particles which are coated by secondary organic and inorganic species (Massoli et al., 2012). The size distribution of COA, however, shows a broad accumulation mode (peaking at $\sim 300 \mathrm{~nm}$ ) at dinner time, such as the COA dominant (57\% of OA) period between 17:00-21:00 on 2 August. The HOA and COA together account for a major fraction of ultrafine mode particles $(>50 \%)$ and show overall different size distributions from secondary species, consistent with the externally mixing characteristics of POA with secondary species.

\subsection{NOA}

The nitrogen-enriched OA (NOA) factor determined in this study shows similar spectral pattern to that reported in Sun et al. (2011c), which is characterized by amine-related peaks, e.g., $\mathrm{CH}_{4} \mathrm{~N}^{+}(m / z 30), \mathrm{C}_{2} \mathrm{H}_{4} \mathrm{~N}^{+}(m / z 42), \mathrm{C}_{3} \mathrm{H}_{8} \mathrm{~N}^{+}$ 


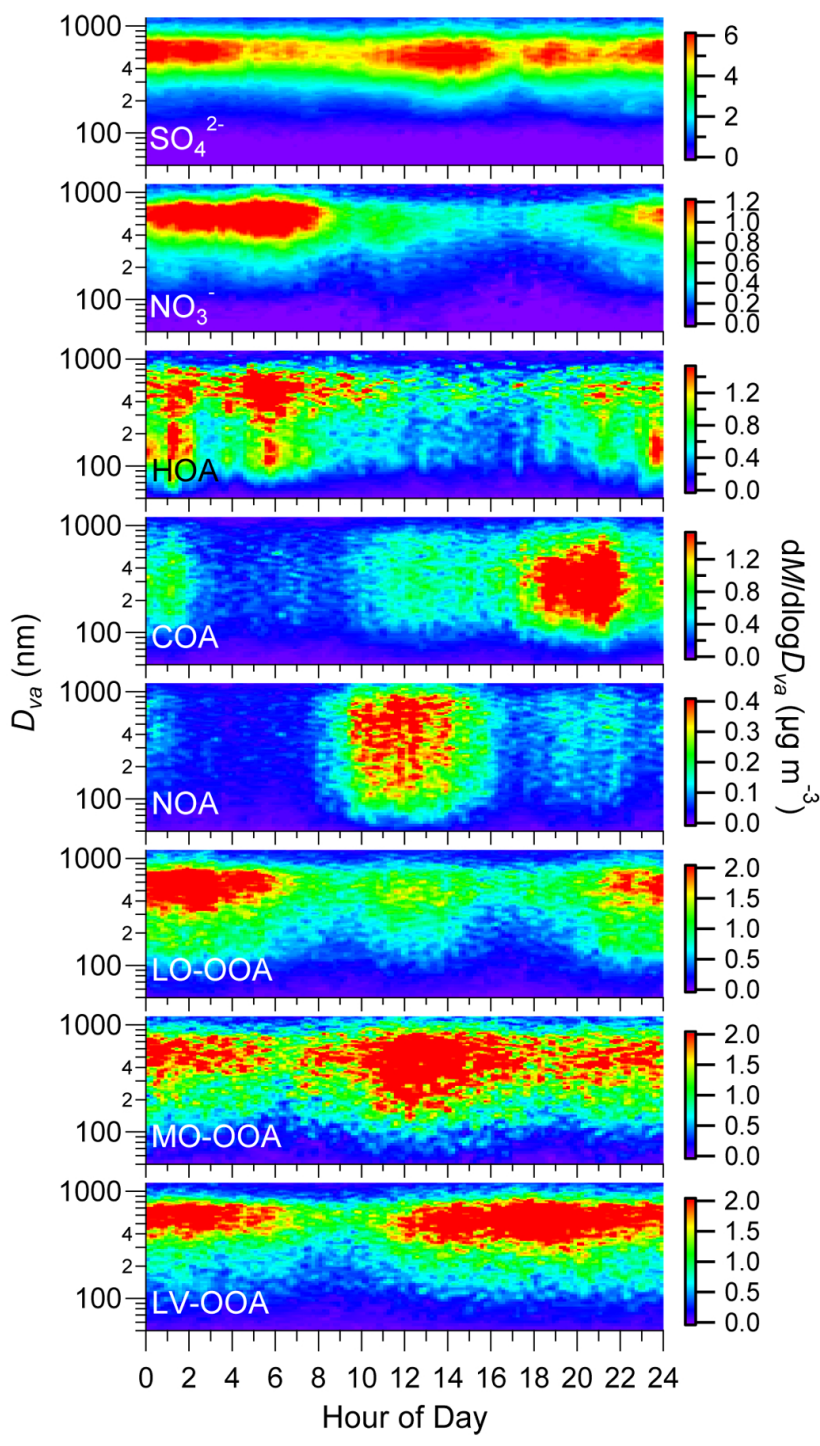

Fig. 6. Diurnal evolution of size distributions of six OA factors from linear regression technique, and sulfate and nitrate. Note, all the size distributions were smoothed by 3 points using binominal algorithm to reduce the noise.

( $m / z$ 58), and $\mathrm{C}_{4} \mathrm{H}_{10} \mathrm{~N}^{+}(m / z$ 72), etc. (McLafferty and Turecek, 1993) and high N/C ratio (0.08 in this study). Consistently, the NOA shows tight correlations with these aminerelated ions, e.g., $r^{2}=0.94$ for $\mathrm{C}_{3} \mathrm{H}_{8} \mathrm{~N}^{+}$. Our previous analysis indicated that the NOA is likely from the amines emitted from industrial and/or marine plankton emissions that are oxidized and condensed on pre-existing particles via acidbase chemistry. A recent study by the on-line measurement of atmospheric amines in Atlanta with an Ambient Pressure Proton Transfer Mass Spectrometer (AmPMS) observed high concentrations of trimethylamine and triethylamine at noon and in the afternoon when the photochemistry is the most intense during the day (Hanson et al., 2011). Similarly, we observed a pronounced NOA noon peak. Also
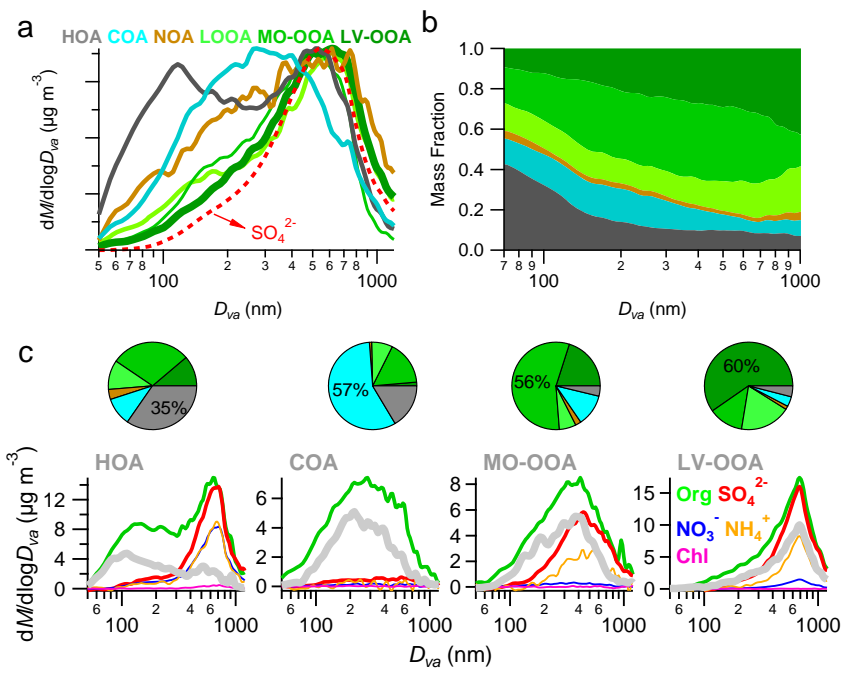

Fig. 7. (a) Average size distributions of six OA factors and sulfate (dash line) for the entire study. Each size distribution is scaled to the maximum. (b) The mass fraction of OA factors as a function of size. (c) shows the average size distributions of NR-PM $\mathrm{M}_{1}$ species for selected periods with OA being dominated by HOA (06:00-08:00, 25 July), COA (17:00-21:00, 2 August), MO-OOA (10:00-14:00, 18 July), and LV-OOA (18:00, 17 July-04:00, 18 July). The size distributions of dominant OA factors are shown as gray lines. The pie charts show the average OA composition for each selected time period.

note that the $\mathrm{NH}_{3}^{+} / \mathrm{NH}_{2}^{+}$ratio of 0.92 is quite different from 1.26 from ammonium nitrate and $\sim 1.2$ in $\mathrm{SO}_{4}$-OA and $\mathrm{NO}_{3}$-OA (Table 2), which likely further indicates the presence of some $\mathrm{N}$-containing compounds in addition to inorganic ammonium. Figure $3 \mathrm{~b}$ shows that the NOA factor mixes a considerable amount of inorganic nitrate and sulfate $(25 \%$ together) from the photochemical production at noon. We further calculated the particle acidity of the NOA factor by comparing the observed $\mathrm{NH}_{4}^{+}\left(\mathrm{NH}_{4}^{+}\right.$measured $)$and that needed to fully neutralize $\mathrm{SO}_{4}^{2-}, \mathrm{NO}_{3}^{-}$, and $\mathrm{Chl}$, i.e., $\mathrm{NH}_{4}^{+}$predict $=18 \times\left(2 \times \mathrm{SO}_{4}^{2-} / 96+\mathrm{NO}_{3}^{-} / 62+\mathrm{Chl} / 35.5\right)(\mathrm{Zhang}$ et al., 2007b). The NOA factor shows a high deficit of $\mathrm{NH}_{4}^{+}$ $\left(\mathrm{NH}_{4}^{+}\right.$measured $/ \mathrm{NH}_{4}^{+}$predict $\left.=0.35\right)$, indicating its acidic properties. The acidic environment facilitates the conversion of gaseous and basic amines to particles followed by the subsequent condensation on pre-existing particles, consistent with the observations of broader size distributions of NOA (Figs. 6 and 7) (Sun et al., 2011c).

\subsection{LO-OOA and MO-OOA}

Only one SV-OOA factor was determined in Sun et al. (2011c). In this study, however, two SV-OOA factors, i.e., a less oxidized LO-OOA and a more oxidized MO-OOA, were identified and show distinct spectral patterns and diurnal profiles. The mass spectrum of LO-OOA is characterized 
Table 2. Summary of the fraction $(\%)$ of selected fragment ions, and ion ratios in eight PMF factors. The average ion ratios for the entire study, and $\mathrm{NO}^{+} / \mathrm{NO}_{2}^{+}$and $\mathrm{NH}_{3}^{+} / \mathrm{NH}_{2}^{+}$from ammonium nitrate are also shown.

\begin{tabular}{|c|c|c|c|c|c|c|c|c|c|c|c|}
\hline Factors & $\mathrm{NO}^{+}$ & $\mathrm{NO}_{2}^{+}$ & $\mathrm{NO}^{+} / \mathrm{NO}_{2}^{+}$ & $\mathrm{NH}_{2}^{+}$ & $\mathrm{NH}_{3}^{+}$ & $\mathrm{NH}_{3}^{+} / \mathrm{NH}_{2}^{+}$ & $\mathrm{SO}^{+}$ & $\mathrm{SO}_{2}^{+}$ & $\mathrm{SO}_{3}^{+}$ & $\mathrm{SO}_{2}^{+} / \mathrm{SO}^{+}$ & $\mathrm{SO}_{3}^{+} / \mathrm{SO}^{+}$ \\
\hline $\mathrm{SO}_{4}-\mathrm{OA}$ & 0.08 & & & 13.1 & 15.7 & 1.20 & 16.1 & 19.6 & 3.29 & 1.22 & 0.20 \\
\hline $\mathrm{NO}_{3}-\mathrm{OA}$ & 43.6 & 12.0 & 3.6 & 9.20 & 11.0 & 1.20 & 1.79 & 2.08 & 0.23 & 1.16 & 0.13 \\
\hline $\mathrm{HOA}$ & 0.55 & & & 0.21 & 0.26 & 1.27 & 0.20 & 0.27 & & 1.33 & \\
\hline $\mathrm{COA}$ & 0.50 & & & 0.21 & 0.01 & 0.04 & 0.40 & 0.60 & & 1.50 & \\
\hline NOA & 6.81 & 1.56 & 4.4 & 1.42 & 1.31 & 0.92 & 3.19 & 4.03 & 0.54 & 1.26 & 0.17 \\
\hline LO-OOA & 0.63 & & & & 0.22 & & 1.14 & 1.42 & 0.71 & 1.25 & 0.62 \\
\hline MO-OOA & 2.87 & 0.31 & 9.4 & 1.83 & 1.66 & 0.91 & 2.97 & 4.08 & & 1.37 & \\
\hline LV-OOA & 0.09 & & & 1.70 & 2.17 & 1.28 & 0.16 & & & & \\
\hline Entire study & & & 3.8 & & & 1.19 & & & & 1.22 & 0.19 \\
\hline $\mathrm{NH}_{4} \mathrm{NO}_{3}$ & & & 3.5 & & & 1.26 & & & & & \\
\hline
\end{tabular}

by two prominent peaks, $m / z 29$ (mainly $\mathrm{CHO}^{+}$) and 43 (mainly $\mathrm{C}_{2} \mathrm{H}_{3} \mathrm{O}^{+}$), and shows much similarity to the $\mathrm{SV}$ OOA component resolved from PMF analysis of thermallydenuded OA spectra during SOAR-1 (Docherty et al., 2011). Also, the low $\mathrm{O} / \mathrm{C}$ ratio $(=0.27)$ and low fraction of $\mathrm{m} / z 44$ $(2.6 \%)$ for LO-OOA are consistent with those of SV-OOA in Docherty et al. (2011). In addition, the LO-OOA show high fraction of $\mathrm{C}_{\mathrm{x}} \mathrm{H}_{\mathrm{y}} \mathrm{O}_{1}^{+}$family $(40 \%)$, most likely from carbonyl or alcohol function groups, while much lower contribution of $\mathrm{C}_{\mathrm{x}} \mathrm{H}_{\mathrm{y}} \mathrm{O}_{2}^{+}$family $(5.3 \%)$, mainly from carboxylic functional groups. The diurnal variation of LO-OOA shows some similarities to nitrate with higher concentration at night and lower concentration during daytime, indicating their similar volatile properties (Docherty et al., 2011). Note that a small noon peak in the diurnal profile of LO-OOA is also observed. The mass spectral features and diurnal variation of LO-OOA likely suggest that (1) LO-OOA is an intermediate aging product from freshly oxidized OA to highly oxidized OA (Docherty et al., 2011), and/or (2) LO-OOA might be driven by the partitioning of organic vapors between gas and particle phase, which is facilitated by the high humidity and low temperature.

The second OOA factor, i.e., MO-OOA, however, shows more oxidized properties with higher $\mathrm{O} / \mathrm{C}$ ratio $(=0.48)$ and higher fraction of $\mathrm{C}_{\mathrm{x}} \mathrm{H}_{\mathrm{y}} \mathrm{O}_{2}^{+}$family $(17 \%)$. The mass spectrum of MO-OOA resembles to that of OOA factor widely observed at other sites ( $\mathrm{Ng}$ et al., 2010), and also biogenic OA (Slowik et al., 2010a; Sun et al., 2011a), although it appears to show relatively lower $m / z$ 43/44 ratio. Particularly, the spectrum of MO-OOA shows much similarity to a local SOA identified from PMF analysis of the unified dataset from AMS and PTR-MS measurements (Slowik et al., 2010b). The local SOA was found to be associated with local photochemical products of acetaldehyde and formaldehyde, indicating that MO-OOA also likely represents a local SOA. The diurnal cycle of MO-OOA presents a pronounced noon peak with the concentration starting to increase at $\sim 09: 00$ and peaking at 13:00. The subsequent decrease of MO-OOA af- ter 13:00 is likely due to the further oxidation of MO-OOA to LV-OOA, consistent with the corresponding increase of LVOOA. Figure 8a shows the time series of MO-OOA, HCHO and $\mathrm{O}_{\mathrm{x}}\left(=\mathrm{O}_{3}+\mathrm{NO}_{2}\right)$. Overall, similar time trends were observed for these three species. The daily correlations between MO-OOA and HCHO, MO-OOA and $\mathrm{O}_{\mathrm{x}}$ are significant during days with intense solar radiation, e.g., $r=0.88$ and 0.90 for MO-OOA vs. HCHO on 22 and 24 July, respectively. Further, the diurnal cycle of MO-OOA is also very similar to that of $\mathrm{HCHO}$ as shown in Fig. 8b. Our previous analysis showed that $\sim 70 \%$ of $\mathrm{HCHO}$ in NYC is from the photochemical production, $\sim 44 \%$ of which is from isoprene oxidation (Lin et al., 2012). All these results suggest that MO-OOA is a SOA product mainly from local photochemical processing, e.g., oxidation of biogenic VOCs. The diurnal size evolution of MO-OOA shows a much broader size distribution during the photochemical processing time, likely indicating the formation of smaller particles from photochemical production followed by condensation on pre-existing particles. Docherty et al. (2011) identified a medium-volatility OOA (MV-OOA) that comprises a higher-volatility MV-OOA (MV-OOA-hv) and a lower-volatility MV-OOA (MV-OOA-lv) fraction during SOAR-1. The two MV-OOA factors correlate with $\mathrm{O}_{\mathrm{x}}$ and WSOC significantly and show very similar diurnal cycles to that of MO-OOA in this study. Detailed analysis suggests that the photochemical processing is the major source of these two factors, consistent with our conclusions.

Further investigation of the case study on 22 July (Sun et al., 2011b) also supports the photochemical production of MO-OOA with the processes co-varying with the solar radiation and the formation of HCHO (Fig. S11). The initial photochemical production in the early morning firstly leads to an increase of MO-OOA, and then followed by an increase of more aged LV-OOA after 13:00. The formation of LVOOA is coincidently corresponding to the decrease of MOOOA, likely indicating an oxidation process from MO-OOA to LV-OOA. The regional transport from the south, however, appears to play more important roles in controlling the 
a

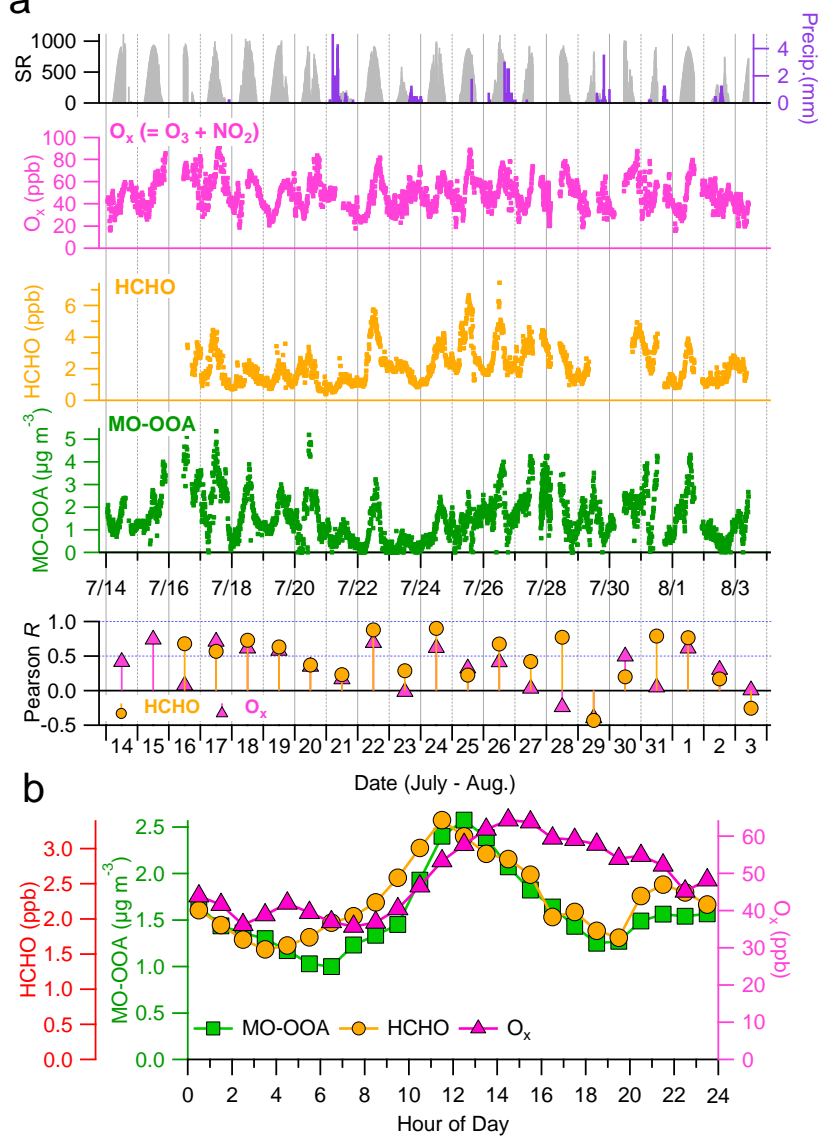

Fig. 8. (a) Time series of solar radiation (SR) and precipitation, $\mathrm{O}_{\mathrm{x}}\left(=\mathrm{NO}_{2}+\mathrm{O}_{3}\right), \mathrm{HCHO}$, and MO-OOA, and daily correlations of MO-OOA vs. HCHO, and MO-OOA vs. $\mathrm{O}_{\mathrm{x}}$. (b) Diurnal profiles of MO-OOA, $\mathrm{HCHO}$, and $\mathrm{O}_{\mathrm{x}}$ for the entire study.

variation of highly aged $\mathrm{OA}$ in $\mathrm{SO}_{4}$-OA factor, which shows a gradual increase from $\sim$ 09:00 until 18:00, in agreement with the air masses from the polluted regions to the south of NYC. Results here indicate that the OA evolution on 22 July is an aging process mixed with local photochemical production and regional transport.

We also note that the MO-OOA factor contains $\sim 20 \%$ of inorganic species, but the fragment ion patterns are quite different from those of pure inorganic species (Table 2). For example, the ion ratio of $\mathrm{NO}^{+} / \mathrm{NO}_{2}^{+}$in $\mathrm{MO}-\mathrm{OOA}$ factor is 9.4 , which is much higher than 3.5 of ammonium nitrate alone. High $\mathrm{NO}^{+} / \mathrm{NO}_{2}^{+}$ratio is an indication for the presence of organic nitrates (Alfarra et al., 2006; Rollins et al., 2010), although the ratio may vary depending on the specific HR-ToFAMS instruments (Farmer et al., 2010). Alfarra et al. (2006) reported a ratio of $\mathrm{NO}^{+} / \mathrm{NO}_{2}^{+}$of 7.5 and 5.1 for the photooxidation of 1,3,5-TMB and $\alpha$-pinene with $\mathrm{NO}_{\mathrm{x}}$, respectively. Similarly, high $\mathrm{NO}^{+} / \mathrm{NO}_{2}^{+}$ratios were also observed for $\mathrm{NO}_{3}$ oxidation of $\beta$-pinene $(\sim 10)$ (Fry et al., 2009), various monoterpene $(\sim 10-15)$ and isoprene $(\sim 5)$ (Bruns et al.,
2010). These results together suggest that $\mathrm{NO}^{+}$and $\mathrm{NO}_{2}^{+}$in MO-OOA factor is likely from the contribution of organic nitrates, especially at noon time, which are formed via the photochemical oxidation of VOCs. The nitrate in MO-OOA factor contributes $\sim 12 \%$ of total nitrate mass. If assuming that $\mathrm{NO}_{\mathrm{x}}^{+}$fragments in MO-OOA are all from organic nitrates and on average account for $\sim 10 \%$ of total organic nitrate signal, we estimate that organic nitrates in NYC contribute $\sim 7 \%$ of total organics. In addition, the ratio of $\mathrm{NH}_{3}^{+} / \mathrm{NH}_{2}^{+}$in MOOOA factor is $\sim 0.9$ which is lower than that of ammonium ( $\sim 1.2$ in this study). This might also indicate the presence of nitrogenated organic compounds in addition to inorganic ammonium. We also observed $\mathrm{SO}^{+}$and $\mathrm{SO}_{2}^{+}$fragment ions, but very minor other sulfate-related ions, e.g., $\mathrm{SO}_{3}^{+}, \mathrm{HSO}_{3}^{+}$, and $\mathrm{H}_{2} \mathrm{SO}_{4}^{+}$in MO-OOA. Unfortunately, we do not have evidence to conclude if these $\mathrm{SO}_{\mathrm{x}}^{+}$ions are from organic sulfates or ammonium sulfate.

\section{$3.5 \quad$ LV-OOA}

The LV-OOA factor determined in this study shows very similar spectral pattern to the previously reported LV-OOA $(\mathrm{Ng}$ et al., 2010; Sun et al., 2011c), which is characterized by high $\mathrm{O} / \mathrm{C}$ ratio $(=0.59)$ and $f_{44}(15 \%)$. The diurnal profile of $\mathrm{LV}-$ OOA is different from those of the other OA factors, showing a gradual increase from noon until late afternoon despite the rising boundary layer. Note that the increase of LV-OOA appears to be associated with the decrease LO-OOA and MOOOA, likely indicating a photochemical oxidation progress from less oxidized OOA to highly oxidized LV-OOA. The size distribution of LV-OOA presents a persistent and single large accumulation across the day. Although LV-OOA is highly aged, it does not mix much with ammonium sulfate and ammonium nitrate, further indicating the different sources of LV-OOA and highly aged $\mathrm{OA}$ in $\mathrm{SO}_{4}-\mathrm{OA}$. Indeed, the correlation between LV-OOA and sulfate from the new $\mathrm{PMF}$ analysis is weaker than that from PMF analysis of OA only ( $r^{2}=0.42$ vs. 0.66$)$. It appears that the previous LVOOA (Sun et al., 2011c) comprises two highly aged OA factors primarily from regional $\left(\mathrm{SO}_{4}-\mathrm{OA}\right)$ and local contributions (LV-OOA). Consistently, the contribution of the sum of highly oxidized $\mathrm{SO}_{4}-\mathrm{OA}(12 \%)$ and LV-OOA $(19 \%)$ to the total OA is close to that of LV-OOA $(\sim 30 \%)$ reported previously (Sun et al., 2011c). Also, the combined size distribution of $\mathrm{LV}-\mathrm{OOA}$ and $\mathrm{SO}_{4}-\mathrm{OA}$ is very similar to that of sulfate (Fig. 7), which is characterized by a large accumulation mode peaking at $\sim 600 \mathrm{~nm}$.

\subsection{Evolution of $\mathrm{OA}$}

To further investigate the evolution of OA, the triangle plot ( $f_{44}$ vs. $\left.f_{43}\right)(\mathrm{Ng}$ et al., 2010$)$ and the Van Krevelen diagram (Heald et al., 2010) are presented in Fig. 9. The HOA, COA, $\mathrm{NO}_{3}-\mathrm{OA}$, and LO-OOA show similar low oxidative properties with varying $f_{43}$, which are located at the bottom of the 

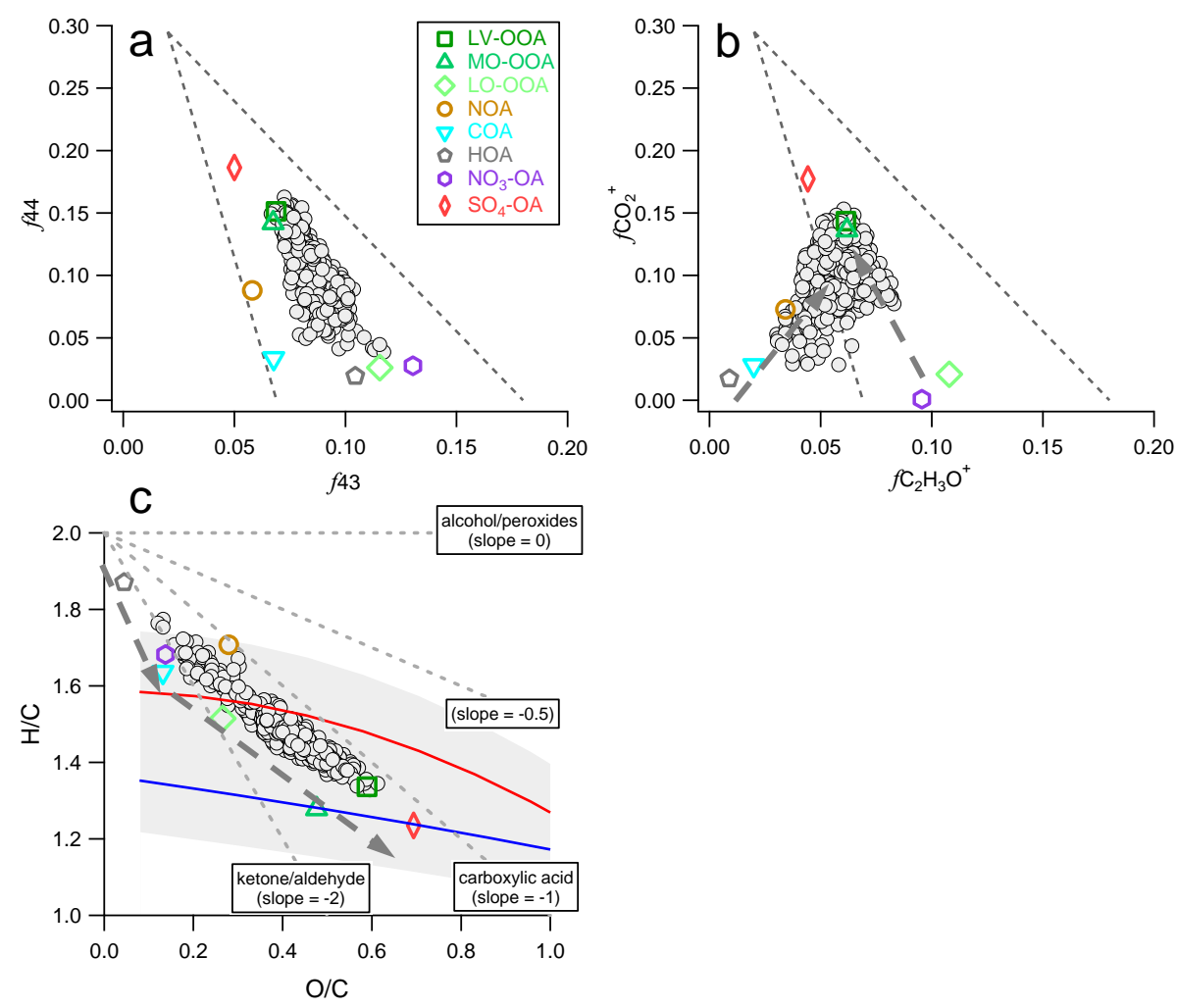

Fig. 9. (a, b) Hourly averaged $f_{44}$ (fraction of $m / z 44$ in OA) vs. $f_{43}$ (fraction of $m / z 43$ in OA), and $f \mathrm{CO}_{2}^{+}$(fraction of $\mathrm{CO}_{2}^{+}$in $\mathrm{OA}$ ) vs. $f \mathrm{C}_{2} \mathrm{H}_{3} \mathrm{O}^{+}$(fraction of $\mathrm{C}_{2} \mathrm{H}_{3} \mathrm{O}^{+}$in $\mathrm{OA}$ ). The $f_{44}$ vs. $f_{43}$ and $f \mathrm{CO}_{2}^{+}$vs. $f \mathrm{C}_{2} \mathrm{H}_{3} \mathrm{O}^{+}$relationships for eight OA factors are also shown. The dash lines in (a) and (b) refer to a triangular region that encompasses ambient OOA factors determined from PMF analyses of 43 AMS datasets (Ng et al., 2010). (c) Van Krevelen diagram for hourly averaged OA and eight OA factors. The dash lines indicate the changes of $\mathrm{H} / \mathrm{C}$ against $\mathrm{O} / \mathrm{C}$ due to adding specific functional groups to an aliphatic carbon (Heald et al., 2010). The red and blue lines are derived from the right and left lines in the triangle plot, and the light gray shaded region denotes $\pm 10 \%$ uncertainty (Ng et al., 2011).

triangular region. As aging progresses, OA evolves to the upper corner and shows more similar oxidative properties to MO-OOA and LV-OOA. However, the ensemble OA never reaches the high oxidation state of $\mathrm{SO}_{4}$-OA. Since the triangle plot represents an integration of OOA factors, in which $m / z 44$ and $m / z 43$ are primarily $\mathrm{CO}_{2}^{+}$and $\mathrm{C}_{2} \mathrm{H}_{3} \mathrm{O}^{+}$, respectively. It is of interest to check the relationship between $f \mathrm{CO}_{2}^{+}$(fraction of $\mathrm{CO}_{2}^{+}$in OA) vs. $f \mathrm{C}_{2} \mathrm{H}_{3} \mathrm{O}^{+}$(fraction of $\mathrm{C}_{2} \mathrm{H}_{3} \mathrm{O}^{+}$in OA) (Fig. 9b). Clearly, different behaviors were observed for $f_{44}$ vs. $f_{43}$. The POA factors of HOA and COA are located at the left-bottom corner with the lowest $f \mathrm{CO}_{2}^{+}$ and $f \mathrm{C}_{2} \mathrm{H}_{3} \mathrm{O}^{+}$, LO-OOA and $\mathrm{NO}_{3}-\mathrm{OA}$, however, reside in the triangular region with high $f \mathrm{C}_{2} \mathrm{H}_{3} \mathrm{O}^{+}$yet similar low $f \mathrm{CO}_{2}^{+}$, indicating their different sources and properties from HOA and COA. It appears that the aging of OA is characterized by two pathways. The initial oxidization of fresh OA, e.g., $\mathrm{HOA} / \mathrm{COA}$ appears to involve a synchronous increase of both $f \mathrm{CO}_{2}^{+}$and $f \mathrm{C}_{2} \mathrm{H}_{3} \mathrm{O}^{+}$, and evolves into the triangular region first. The further oxidation of less oxidized OA, e.g., LO-OOA/ $\mathrm{NO}_{3}-\mathrm{OA}$, however, appears to follow a trend with a decrease of $f \mathrm{C}_{2} \mathrm{H}_{3} \mathrm{O}^{+}$and increase of $f \mathrm{CO}_{2}^{+}$. The two evolving trends are consistent with the evolution of $\mathrm{H} / \mathrm{C}$ vs. O/C in the Van Krevelen diagram. The initial oxidation of POA shows a steeper slope than -1 , likely driven by the functionalization by incorporating carbonyl groups ( $\mathrm{Ng}$ et al., 2011). The further oxidation of OA shows a shallower slope $(\sim-0.8)$, most likely from the additions of both acid and alcohol functional groups with little fragmentation $(\mathrm{Ng}$ et al., 2011). The evolution processes also lead to a change of the size distributions of OA factors (Fig. 7), and the size appears to progress from smaller to larger particles as a function of oxidization state.

\section{Conclusions}

PMF analysis was performed for the first time to the combined HR mass spectral matrices of organic and inorganic aerosols from the HR-ToF-AMS measurements conducted at QC in NYC in summer 2009. In this study, eight factors were identified, including a $\mathrm{SO}_{4}-\mathrm{OA}$ that contains primarily ammonium sulfate and highly oxidized $\mathrm{OA}$ from regional scale, a $\mathrm{NO}_{3}$-OA that contains primarily ammonium nitrate, two POA factors, i.e., HOA and COA from traffic emissions 
and cooking activities, respectively, an amine-related NOA that mixes with acidic ammonium sulfate and nitrate from local photochemical production, and three OOA factors, i.e., a LV-OOA likely from further oxidation of OOA, a more oxidized OOA (MO-OOA) and a less oxidized OOA (LOOOA). Each OA factor shows distinct mass spectral profile and diurnal variation patterns that reflect its unique sources and photochemical processes. The HOA and COA factors contain minimum signals from inorganic species (ammonium, sulfate and nitrate), highlighting the different sources and processing characteristics between POA and inorganic secondary species. In comparison to the previous PMF analysis results reported in Sun et al. (2011c), a new MO-OOA factor representing SOA from local photochemical production was identified. The diurnal profile of MO-OOA shows a pronounced noon peak and correlates well with $\mathrm{HCHO}$ and $\mathrm{O}_{\mathrm{x}}$. The $\mathrm{NO}^{+} / \mathrm{NO}_{2}^{+}$ratio in MO-OOA is much higher than that of ammonium nitrate, indicating the formation of organic nitrates during the photochemical processing. The LO-OOA, however, appears to be mainly driven by gas-to-particle partitioning. The NOA factor shows a high deficit of ammonium and highly acidic, which facilitates the transformation of alkaline amines to aerosol particles in acidic environments. Further investigations of the evolution of OA factors suggest that the initial oxidation of POA and further oxidation of OOA appears to follow different mechanisms. The evolution of the size distributions of OA factors is also distinct, but shows an overall trend of progressing from smaller to larger particle mode as a function of carbon oxidation state. Our results show that PMF analysis of the combined AMS HR matrices is an effective approach to improve our understanding on the sources, chemical characteristics, and evolution processes of atmospheric aerosols.

\section{Supplementary material related to this article is available online at: http://www.atmos-chem-phys.net/12/ 8537/2012/acp-12-8537-2012-supplement.pdf.}

Acknowledgements. This research was supported by the Office of Science (BER), US Department of Energy (Grant \#DEFG0208ER64627, DESC0002191), the National Natural Science Foundation of China (Grant \#41175108), and in part by the New York State Energy Research and Development Authority (NYSERDA Contract \#10602), and New York State Office of Science Technology and Academic Research (NYSTAR Contract \#3538479). We thank Weinai Chen, Minsuk Bae, Yuchi Lin, Huiming Huang, Olga Hogrefe, Brian Frank, and our Aerodyne colleagues for their assistance in this study, the New York State Department of Environmental Conservation for use of their facility, and the Queens College administration and staff for hosting this study.

Edited by: A. Kiendler-Scharr

\section{References}

Aiken, A. C., Salcedo, D., Cubison, M. J., Huffman, J. A., DeCarlo, P. F., Ulbrich, I. M., Docherty, K. S., Sueper, D., Kimmel, J. R., Worsnop, D. R., Trimborn, A., Northway, M., Stone, E. A., Schauer, J. J., Volkamer, R. M., Fortner, E., de Foy, B., Wang, J., Laskin, A., Shutthanandan, V., Zheng, J., Zhang, R., Gaffney, J., Marley, N. A., Paredes-Miranda, G., Arnott, W. P., Molina, L. T., Sosa, G., and Jimenez, J. L.: Mexico City aerosol analysis during MILAGRO using high resolution aerosol mass spectrometry at the urban supersite (T0) - Part 1: Fine particle composition and organic source apportionment, Atmos. Chem. Phys., 9, 6633-6653, doi:10.5194/acp-9-6633-2009, 2009.

Alfarra, M. R., Paulsen, D., Gysel, M., Garforth, A. A., Dommen, J., Prévôt, A. S. H., Worsnop, D. R., Baltensperger, U., and Coe, H.: A mass spectrometric study of secondary organic aerosols formed from the photooxidation of anthropogenic and biogenic precursors in a reaction chamber, Atmos. Chem. Phys., 6, 52795293, doi:10.5194/acp-6-5279-2006, 2006.

Allan, J. D., Jimenez, J. L., Williams, P. I., Alfarra, M. R., Bower, K. N., Jayne, J. T., Coe, H., and Worsnop, D. R.: Quantitative sampling using an Aerodyne Aerosol Mass Spectrometer. Part 1: Techniques of data interpretation and error analysis, J. Geophys. Res.-Atmos., 108, 4090, doi:4010.1029/2002JD002358, 2003.

Allan, J. D., Williams, P. I., Morgan, W. T., Martin, C. L., Flynn, M. J., Lee, J., Nemitz, E., Phillips, G. J., Gallagher, M. W., and Coe, H.: Contributions from transport, solid fuel burning and cooking to primary organic aerosols in two UK cities, Atmos. Chem. Phys., 10, 647-668, doi:10.5194/acp-10-647-2010, 2010.

Bruns, E. A., Perraud, V. R., Zelenyuk, A., Ezell, M. J., Johnson, S. N., Yu, Y., Imre, D., Finlayson-Pitts, B. J., and Alexander, M. L.: Comparison of FTIR and Particle Mass Spectrometry for the Measurement of Particulate Organic Nitrates, Environ. Sci. Technol., 44, 1056-1061, doi:10.1021/es9029864, 2010.

Canagaratna, M. R., Jayne, J. T., Ghertner, D. A., Herndon, S., Shi, Q., Jimenez, J. L., Silva, P. J., Williams, P., Lanni, T., Drewnick, F., Demerjian, K. L., Kolb, C. E., and Worsnop, D. R.: Chase studies of particulate emissions from in-use New York City vehicles, Aerosol Sci. Tech., 38, 555-573, 2004.

Chang, R. Y.-W., Leck, C., Graus, M., Müller, M., Paatero, J., Burkhart, J. F., Stohl, A., Orr, L. H., Hayden, K., Li, S.-M., Hansel, A., Tjernström, M., Leaitch, W. R., and Abbatt, J. P. D.: Aerosol composition and sources in the central Arctic Ocean during ASCOS, Atmos. Chem. Phys., 11, 10619-10636, doi:10.5194/acp-11-10619-2011, 2011.

DeCarlo, P. F., Kimmel, J. R., Trimborn, A., Northway, M. J., Jayne, J. T., Aiken, A. C., Gonin, M., Fuhrer, K., Horvath, T., Docherty, K. S., Worsnop, D. R., and Jimenez, J. L.: Field-Deployable, High-Resolution, Time-of-Flight Aerosol Mass Spectrometer, Anal. Chem., 78, 8281-8289, 2006.

DeCarlo, P. F., Ulbrich, I. M., Crounse, J., de Foy, B., Dunlea, E. J., Aiken, A. C., Knapp, D., Weinheimer, A. J., Campos, T., Wennberg, P. O., and Jimenez, J. L.: Investigation of the sources and processing of organic aerosol over the Central Mexican Plateau from aircraft measurements during MILAGRO, Atmos. Chem. Phys., 10, 5257-5280, doi:10.5194/acp-10-52572010, 2010.

Docherty, K. S., Aiken, A. C., Huffman, J. A., Ulbrich, I. M., DeCarlo, P. F., Sueper, D., Worsnop, D. R., Snyder, D. C., Peltier, R. E., Weber, R. J., Grover, B. D., Eatough, D. J., Williams, B. 
J., Goldstein, A. H., Ziemann, P. J., and Jimenez, J. L.: The 2005 Study of Organic Aerosols at Riverside (SOAR-1): instrumental intercomparisons and fine particle composition, Atmos. Chem. Phys., 11, 12387-12420, doi:10.5194/acp-11-12387-2011, 2011.

Drewnick, F., Hings, S. S., DeCarlo, P. F., Jayne, J. T., Gonin, M., Fuhrer, K., Weimer, S., Jimenez, J. L., Demerjian, K. L., Borrmann, S., and Worsnop, D. R.: A new Time-of-Flight Aerosol Mass Spectrometer (ToF-AMS) - Instrument description and first field deployment., Aerosol Sci. Tech., 39, 637-658, 2005.

Dzepina, K., Volkamer, R. M., Madronich, S., Tulet, P., Ulbrich, I. M., Zhang, Q., Cappa, C. D., Ziemann, P. J., and Jimenez, J. L.: Evaluation of recently-proposed secondary organic aerosol models for a case study in Mexico City, Atmos. Chem. Phys., 9, 5681-5709, doi:10.5194/acp-9-5681-2009, 2009.

Farmer, D. K., Matsunaga, A., Docherty, K. S., Surratt, J. D., Seinfeld, J. H., Ziemann, P. J., and Jimenez, J. L.: Response of an aerosol mass spectrometer to organonitrates and organosulfates and implications for atmospheric chemistry, P. Natl. Acad. Sci. USA, 107, 6670-6675, doi:10.1073/pnas.0912340107, 2010.

Forster, P., Ramaswamy, V., Artaxo, P., Berntsen, T., Betts, R., Fahey, D. W., Haywood, J., Lean, J., Lowe, D. C., Myhre, G., Nganga, J., Prinn, R., Raga, G., Schulz, M., and Dorland, R. V.: Changes in Atmospheric Constituents and in Radiative Forcing, in: Climate Change 2007: The Physical Science Basis. Contribution of Working Group I to the Fourth Assessment Report of the Intergovernmental Panel on Climate Change, edited by: Solomon, S., Qin, D., Manning, M., Chen, Z., Marquis, M., Averyt, K. B., Tignor, M., and Miller, H. L.: Cambridge University Press, Cambridge, United Kingdom and New York, NY, USA, 2007

Fry, J. L., Kiendler-Scharr, A., Rollins, A. W., Wooldridge, P. J., Brown, S. S., Fuchs, H., Dubé, W., Mensah, A., dal Maso, M., Tillmann, R., Dorn, H.-P., Brauers, T., and Cohen, R. C.: Organic nitrate and secondary organic aerosol yield from $\mathrm{NO}_{3}$ oxidation of $\beta$-pinene evaluated using a gas-phase kinetics/aerosol partitioning model, Atmos. Chem. Phys., 9, 14311449, doi:10.5194/acp-9-1431-2009, 2009.

Ge, X., Setyan, A., Sun, Y., and Zhang, Q.: Primary and secondary organic aerosols in Fresno, California during wintertime: Results from high resolution aerosol mass spectrometry, J. Geophys. Res., doi:10.1029/2012JD018026, in press, 2012.

Hanson, D. R., McMurry, P. H., Jiang, J., Tanner, D., and Huey, L. G.: Ambient Pressure Proton Transfer Mass Spectrometry: Detection of Amines and Ammonia, Environ. Sci. Technol., 45, 8881-8888, doi:10.1021/es201819a, 2011.

Heald, C. L., Jacob, D. J., Park, R. J., Russell, L. M., Huebert, B. J., Seinfeld, J. H., Liao, H., and Weber, R. J.: A large organic aerosol source in the free troposphere missing from current models, Geophys. Res. Lett., 32, L18809, doi:10.1029/2005GL023831, 2005.

Heald, C. L., Kroll, J. H., Jimenez, J. L., Docherty, K. S., DeCarlo, P. F., Aiken, A. C., Chen, Q., Martin, S. T., Farmer, D. K., and Artaxo, P.: A simplified description of the evolution of organic aerosol composition in the atmosphere, Geophys. Res. Lett., 37, L08803, doi:10.1029/2010g1042737, 2010.

Heald, C. L., Coe, H., Jimenez, J. L., Weber, R. J., Bahreini, R., Middlebrook, A. M., Russell, L. M., Jolleys, M., Fu, T.-M., Allan, J. D., Bower, K. N., Capes, G., Crosier, J., Morgan, W. T., Robinson, N. H., Williams, P. I., Cubison, M. J., DeCarlo, P. F., and Dunlea, E. J.: Exploring the vertical profile of atmo- spheric organic aerosol: comparing 17 aircraft field campaigns with a global model, Atmos. Chem. Phys., 11, 12673-12696, doi:10.5194/acp-11-12673-2011, 2011.

Jayne, J. T., Leard, D. C., Zhang, X., Davidovits, P., Smith, K. A., Kolb, C. E., and Worsnop, D. R.: Development of an aerosol mass spectrometer for size and composition analysis of submicron particles, Aerosol Sci. Tech., 33, 49-70, 2000.

Jimenez, J. L., Canagaratna, M. R., Donahue, N. M., Prevot, A. S. H., Zhang, Q., Kroll, J. H., DeCarlo, P. F., Allan, J. D., Coe, H., Ng, N. L., Aiken, A. C., Docherty, K. S., Ulbrich, I. M., Grieshop, A. P., Robinson, A. L., Duplissy, J., Smith, J. D., Wilson, K. R., Lanz, V. A., Hueglin, C., Sun, Y. L., Tian, J., Laaksonen, A., Raatikainen, T., Rautiainen, J., Vaattovaara, P., Ehn, M., Kulmala, M., Tomlinson, J. M., Collins, D. R., Cubison, M. J., E, Dunlea, J., Huffman, J. A., Onasch, T. B., Alfarra, M. R., Williams, P. I., Bower, K., Kondo, Y., Schneider, J., Drewnick, F., Borrmann, S., Weimer, S., Demerjian, K., Salcedo, D., Cottrell, L., Griffin, R., Takami, A., Miyoshi, T., Hatakeyama, S., Shimono, A., Sun, J. Y., Zhang, Y. M., Dzepina, K., Kimmel, J. R., Sueper, D., Jayne, J. T., Herndon, S. C., Trimborn, A. M., Williams, L. R., Wood, E. C., Middlebrook, A. M., Kolb, C. E., Baltensperger, U., and Worsnop, D. R.: Evolution of organic aerosols in the atmosphere, Science, 326, 1525-1529, doi:10.1126/science.1180353, 2009.

Khan, B., Hays, M. D., Geron, C., and Jetter, J.: Differences in the OC/EC Ratios that Characterize Ambient and Source Aerosols due to Thermal-Optical Analysis, Aerosol Sci. Tech., 46, $127-$ 137, doi:10.1080/02786826.2011.609194, 2011.

Lall, R. and Thurston, G. D.: Identifying and quantifying transported vs. local sources of New York City $\mathrm{PM}_{2.5}$ fine particulate matter air pollution, Atmos. Environ., 40, 333-346, 2006.

Lanz, V. A., Alfarra, M. R., Baltensperger, U., Buchmann, B., Hueglin, C., and Prévôt, A. S. H.: Source apportionment of submicron organic aerosols at an urban site by factor analytical modelling of aerosol mass spectra, Atmos. Chem. Phys., 7, 15031522, doi:10.5194/acp-7-1503-2007, 2007.

Li, Z., Hopke, P. K., Husain, L., Qureshi, S., Dutkiewicz, V. A., Schwab, J. J., Drewnick, F., and Demerjian, K. L.: Sources of fine particle composition in New York city, Atmos. Environ., 38, 6521-6529, 2004.

Lin, Y. C., Schwab, J. J., Demerjian, K. L., Bae, M.-S., Chen, W.N., Sun, Y., Zhang, Q., Hung, H.-M., and Perry, J.: Summertime Formaldehyde Observations in New York City: Ambient levels, Sources and Its Contribution to $\mathrm{HO}_{\mathrm{x}}$ Radicals, J. Geophys. Res., 117, D08305, doi:10.1029/2011JD016504, 2012.

Massoli, P., Fortner, E. C., Canagaratna, M. R., Williams, L. R., Zhang, Q., Sun, Y., Schwab, J. J., Trimborn, A., Onasch, T. B., Demerjian, K. L., Kolb, C. E., Worsnop, D. R., and Jayne, J. T.: Pollution Gradients and Chemical Characterization of Particulate Matter from Vehicular Traffic Near Major Roadways: Results from the 2009 Queens College Air Quality Study in NYC, Aerosol Sci. Tech., 46, 1201-1218, doi:10.1080/02786826.2012.701784, 2012.

McLafferty, F. W. and Turecek, F.: Interpretation of Mass Spectra, University Science Books, Mill Valley, California, 1993.

Mohr, C., Huffman, J. A., Cubison, M. J., Aiken, A. C., Docherty, K. S., Kimmel, J. R., Ulbrich, I. M., Hannigan, M., and Jimenez, J. L.: Characterization of primary organic aerosol emissions from meat cooking, trash burning, and motor vehicles with 
High-Resolution Aerosol Mass Spectrometry and comparison with ambient and chamber observations, Environ. Sci. Technol., 43, 2443-2449, doi:10.1021/es8011518, 2009.

Mohr, C., DeCarlo, P. F., Heringa, M. F., Chirico, R., Slowik, J. G., Richter, R., Reche, C., Alastuey, A., Querol, X., Seco, R., Peñuelas, J., Jiménez, J. L., Crippa, M., Zimmermann, R., Baltensperger, U., and Prévôt, A. S. H.: Identification and quantification of organic aerosol from cooking and other sources in Barcelona using aerosol mass spectrometer data, Atmos. Chem. Phys., 12, 1649-1665, doi:10.5194/acp-12-1649-2012, 2012.

Ng, N. L., Canagaratna, M. R., Zhang, Q., Jimenez, J. L., Tian, J., Ulbrich, I. M., Kroll, J. H., Docherty, K. S., Chhabra, P. S., Bahreini, R., Murphy, S. M., Seinfeld, J. H., Hildebrandt, L., Donahue, N. M., DeCarlo, P. F., Lanz, V. A., Prévôt, A. S. H., Dinar, E., Rudich, Y., and Worsnop, D. R.: Organic aerosol components observed in Northern Hemispheric datasets from Aerosol Mass Spectrometry, Atmos. Chem. Phys., 10, 46254641, doi:10.5194/acp-10-4625-2010, 2010.

Ng, N. L., Canagaratna, M. R., Jimenez, J. L., Chhabra, P. S., Seinfeld, J. H., and Worsnop, D. R.: Changes in organic aerosol composition with aging inferred from aerosol mass spectra, Atmos. Chem. Phys., 11, 6465-6474, doi:10.5194/acp-11-64652011, 2011.

Paatero, P. and Tapper, U.: Positive matrix factorization: A nonnegative factor model with optimal utilization of error estimates of data values, Environmetrics, 5, 111-126, 1994.

Pope III, C. A., Burnett, R. T., Thun, M. J., Calle, E. E., Krewski, D., Ito, K., and Thurston, G. D.: Lung cancer, cardiopulmonary mortality, and long-term exposure to fine particulate air pollution, JAMA-J. Am. Med. Assoc., 287, 1132-1141, 2002.

Pope III, C. A., Ezzati, M., and Dockery, D. W.: Fine-particulate air pollution and life expectancy in the United States, N. Engl. J. Med., 360, 376-386, doi:10.1056/NEJMsa0805646, 2009.

Qin, Y., Kim, E., and Hopke, P. K.: The concentrations and sources of $\mathrm{PM}_{2.5}$ in metropolitan New York City, Atmos. Environ., 40, 312-332, 2006.

Rollins, A. W., Fry, J. L., Hunter, J. F., Kroll, J. H., Worsnop, D. R., Singaram, S. W., and Cohen, R. C.: Elemental analysis of aerosol organic nitrates with electron ionization high-resolution mass spectrometry, Atmos. Meas. Tech., 3, 301-310, doi:10.5194/amt3-301-2010, 2010.

Schauer, J. J. and Cass, G. R.: Source apportionment of wintertime gas-phase and particle-phase air pollutants using organic compounds as tracers, Environ. Sci. Technol., 34, 1821-1832, 2000.

Slowik, J. G., Stroud, C., Bottenheim, J. W., Brickell, P. C., Chang, R. Y.-W., Liggio, J., Makar, P. A., Martin, R. V., Moran, M. D., Shantz, N. C., Sjostedt, S. J., van Donkelaar, A., Vlasenko, A., Wiebe, H. A., Xia, A. G., Zhang, J., Leaitch, W. R., and Abbatt, J. P. D.: Characterization of a large biogenic secondary organic aerosol event from eastern Canadian forests, Atmos. Chem. Phys., 10, 2825-2845, doi:10.5194/acp-10-2825-2010, 2010a.

Slowik, J. G., Vlasenko, A., McGuire, M., Evans, G. J., and Abbatt, J. P. D.: Simultaneous factor analysis of organic particle and gas mass spectra: AMS and PTR-MS measurements at an urban site, Atmos. Chem. Phys., 10, 1969-1988, doi:10.5194/acp-10-19692010, 2010b.

Sun, Y., Zhang, Q., Zheng, M., Ding, X., Edgerton, E. S., and Wang, $\mathrm{X}$.: Characterization and source apportionment of water-soluble organic matter in atmospheric fine particles $\left(\mathrm{PM}_{2.5}\right)$ with High-
Resolution Aerosol Mass Spectrometry and GC-MS, Environ. Sci. Technol., 45, 4854-4861, doi:10.1021/es200162h, 2011a.

Sun, Y. L., Zhang, Q., Schwab, J. J., Chen, W. N., Bae, M. S., Lin, Y. C., Hung, H. M., and Demerjian, K. L.: A case study of aerosol processing and evolution in summer in New York City, Atmos. Chem. Phys., 11, 12737-12750, doi:10.5194/acp11-12737-2011, $2011 \mathrm{~b}$.

Sun, Y.-L., Zhang, Q., Schwab, J. J., Demerjian, K. L., Chen, W.N., Bae, M.-S., Hung, H.-M., Hogrefe, O., Frank, B., Rattigan, O. V., and Lin, Y.-C.: Characterization of the sources and processes of organic and inorganic aerosols in New York city with a high-resolution time-of-flight aerosol mass apectrometer, Atmos. Chem. Phys., 11, 1581-1602, doi:10.5194/acp-11-15812011, 2011c.

Turpin, B. J. and Huntzicker, J. J.: Identification of secondary organic aerosol episodes and quantitation of primary and secondary organic aerosol concentrations during SCAQS, Atmos. Environ., 29, 3527-3544, 1995.

Ulbrich, I. M., Canagaratna, M. R., Zhang, Q., Worsnop, D. R., and Jimenez, J. L.: Interpretation of organic components from Positive Matrix Factorization of aerosol mass spectrometric data, Atmos. Chem. Phys., 9, 2891-2918, doi:10.5194/acp-9-2891-2009, 2009.

Ulbrich, I. M., Canagaratna, M. R., Cubison, M. J., Zhang, Q., Ng, N. L., Aiken, A. C., and Jimenez, J. L.: Three-dimensional factorization of size-resolved organic aerosol mass spectra from Mexico City, Atmos. Meas. Tech., 5, 195-224, doi:10.5194/amt-5195-2012, 2012.

Volkamer, R., Jimenez, J. L., Martini, F. S., Dzepina, K., Zhang, Q., Salcedo, D., Molina, L. T., Molina, M. J., and Worsnop, D. R.: Secondary organic aerosol formation from anthropogenic VOCs: Rapid and higher than expected, Geophys. Res. Lett., 33, L17811, doi:10.1029/2006GL026899, 2006.

Watson, J. G.: Visibility: Science and regulation, J. Air Waste Manage., 52, 628-713, 2002.

Wood, E. C., Canagaratna, M. R., Herndon, S. C., Onasch, T. B., Kolb, C. E., Worsnop, D. R., Kroll, J. H., Knighton, W. B., Seila, R., Zavala, M., Molina, L. T., DeCarlo, P. F., Jimenez, J. L., Weinheimer, A. J., Knapp, D. J., Jobson, B. T., Stutz, J., Kuster, W. C., and Williams, E. J.: Investigation of the correlation between odd oxygen and secondary organic aerosol in Mexico City and Houston, Atmos. Chem. Phys., 10, 8947-8968, doi:10.5194/acp-10-8947-2010, 2010.

Zhang, Q., Alfarra, M. R., Worsnop, D. R., Allan, J. D., Coe, H., Canagaratna, M. R., and Jimenez, J. L.: Deconvolution and quantification of hydrocarbon-like and oxygenated organic aerosols based on aerosol mass spectrometry, Environ. Sci. Technol., 39, 4938-4952, doi:4910.1021/es0485681, 2005a.

Zhang, Q., Worsnop, D. R., Canagaratna, M. R., and Jimenez, J. L.: Hydrocarbon-like and oxygenated organic aerosols in Pittsburgh: insights into sources and processes of organic aerosols, Atmos. Chem. Phys., 5, 3289-3311, doi:10.5194/acp-5-32892005, 2005b.

Zhang, Q., Jimenez, J. L., Canagaratna, M. R., Allan, J. D., Coe, H., Ulbrich, I., Alfarra, M. R., Takami, A., Middlebrook, A. M., Sun, Y. L., Dzepina, K., Dunlea, E., Docherty, K., DeCarlo, P. F., Salcedo, D., Onasch, T., Jayne, J. T., Miyoshi, T., Shimono, A., Hatakeyama, S., Takegawa, N., Kondo, Y., Schneider, J., Drewnick, F., Weimer, S., Demerjian, K., Williams, P., Bower, 
K., Bahreini, R., Cottrell, L., Griffin, R. J., Rautiainen, J., Sun, J. Y., Zhang, Y. M., and Worsnop, D. R.: Ubiquity and dominance of oxygenated species in organic aerosols in anthropogenicallyinfluenced northern hemisphere mid-latitudes, Geophys. Res. Lett., 34, L13801, doi:10.1029/2007GL029979, 2007a.

Zhang, Q., Jimenez, J. L., Worsnop, D. R., and Canagaratna, M.: A case study of urban particle acidity and its effect on secondary organic aerosol, Environ. Sci. Technol., 41, 3213-3219, $2007 \mathrm{~b}$.

Zhang, Q., Jimenez, J., Canagaratna, M., Ulbrich, I., Ng, N., Worsnop, D., and Sun, Y.: Understanding atmospheric organic aerosols via factor analysis of aerosol mass spectrometry: a review, Anal. Bioanal. Chem., 401, 3045-3067, doi:10.1007/s00216-011-5355-y, 2011.
Zheng, M., Cass, G. R., Schauer, J. J., and Edgerton, E. S.: Source Apportionment of $\mathrm{PM}_{2.5}$ in the Southeastern United States Using Solvent-Extractable Organic Compounds as Tracers, Environ. Sci. Technol., 36, 2361-2371, 2002. 